Review

\title{
Evolution of Singlet Oxygen by Activating Peroxydisulfate and Peroxymonosulfate: A Review
}

\author{
Guangfeng Xiao, Tiantian Xu, Muhammad Faheem, Yanxing Xi, Ting Zhou, Haseeb Tufail Moryani, Jianguo Bao \\ and Jiangkun $\mathrm{Du} *$ (D)
}

check for

updates

Citation: Xiao, G.; Xu, T.; Faheem, M.; Xi, Y.; Zhou, T.; Moryani, H.T.; Bao, J.; Du, J. Evolution of Singlet Oxygen by Activating

Peroxydisulfate and

Peroxymonosulfate: A Review. Int. J. Environ. Res. Public Health 2021, 18, 3344. https://doi.org/10.3390/ ijerph18073344

Academic Editor: Chunping Yang

Received: 8 March 2021

Accepted: 19 March 2021

Published: 24 March 2021

Publisher's Note: MDPI stays neutral with regard to jurisdictional claims in published maps and institutional affiliations.

Copyright: (c) 2021 by the authors. Licensee MDPI, Basel, Switzerland. This article is an open access article distributed under the terms and conditions of the Creative Commons Attribution (CC BY) license (https:// creativecommons.org/licenses/by/ $4.0 /)$.
School of Environmental Studies, China University of Geosciences, Wuhan 430074, China; doujiang1226@126.com (G.X.); xutiantian202102@163.com (T.X.); Faheem@cug.edu.cn (M.F.); xiyanxing525@163.com (Y.X.); 18202721355@163.com (T.Z.); haseebmoriani@cug.edu.cn (H.T.M.); bjianguo@cug.edu.cn (J.B.)

* Correspondence: dujk@cug.edu.cn

Abstract: Advanced oxidation processes (AOPs) based on peroxydisulfate (PDS) or peroxymonosulfate (PMS) activation have attracted much research attention in the last decade for the degradation of recalcitrant organic contaminants. Sulfate $\left(\mathrm{SO}_{4}{ }^{\bullet-}\right)$ and hydroxyl $\left({ }^{\bullet} \mathrm{OH}\right)$ radicals are most frequently generated from catalytic PDS/PMS decomposition by thermal, base, irradiation, transition metals and carbon materials. In addition, increasingly more recent studies have reported the involvement of singlet oxygen $\left({ }^{1} \mathrm{O}_{2}\right)$ during PDS/PMS-based AOPs. Typically, ${ }^{1} \mathrm{O}_{2}$ can be produced either along with $\mathrm{SO}_{4}{ }^{\bullet-}$ and ${ }^{\bullet} \mathrm{OH}$ or discovered as the dominant reactive oxygen species (ROSs) for pollutants degradation. This paper reviews recent advances in ${ }^{1} \mathrm{O}_{2}$ generation during PDS/PMS activation. First, it introduces the basic chemistry of ${ }^{1} \mathrm{O}_{2}$, its oxidation properties and detection methodologies. Furthermore, it elaborates different activation strategies/techniques, including homogeneous and heterogeneous systems, and discusses the possible reaction mechanisms to give an overview of the principle of ${ }^{1} \mathrm{O}_{2}$ production by activating PDS/PMS. Moreover, although ${ }^{1} \mathrm{O}_{2}$ has shown promising features such as high degradation selectivity and anti-interference capability, its production pathways and mechanisms remain controversial in the present literatures. Therefore, this study identifies the research gaps and proposes future perspectives in the aspects of novel catalysts and related mechanisms.

Keywords: singlet oxygen; peroxydisulfate; peroxymonosulfate; activation; organic contaminants; degradation

\section{Introduction}

Nowadays the wide occurrence of emerging organic and refractory pollutants in the soil and aquatic environment has raised much concern about water and food security. Advanced oxidation processes (AOPs) are feasible options to remove these undesirable pollutants by producing reactive oxidizing species (ROSs), such as hydroxyl radicals $\left({ }^{\bullet} \mathrm{OH}\right.$, $\left.\mathrm{E}^{0}=2.8 \mathrm{~V}\right)$ and sulfate radicals $\left(\mathrm{SO}_{4}^{\bullet-}, \mathrm{E}^{0}=2.5-3.1 \mathrm{~V}\right)[1,2]$. In the past two decades, AOPs using peroxydisulfate (PDS, $\mathrm{S}_{2} \mathrm{O}_{8}{ }^{2-}$ ) and peroxymonosulfate (PMS, $\mathrm{HSO}_{5}{ }^{-}$) as oxidants have attracted much attention for the non-selective degradation of a wide range of pollutants. Because PDS and PMS are solid powders, they can be easily delivered. Compared to $\mathrm{H}_{2} \mathrm{O}_{2}$, the anions of PDS/PMS can remain stable in water much longer until being properly activated. In addition, PMS and PDS-based AOPs can be smoothly carried out over a broad solution $\mathrm{pH}$ range from acid to alkaline while $\mathrm{H}_{2} \mathrm{O}_{2}$-based Fenton processes require strict acidic conditions. Typically, PDS and PMS should be properly activated by breaking the $\mathrm{O}-\mathrm{O}$ bond with the aid of ultraviolet, heat, alkali or metallic catalysts and so on. $\mathrm{SO}_{4}{ }^{\bullet-}$ and ${ }^{\bullet} \mathrm{OH}$ are commonly produced as the main ROSs [3]. Despite how promising both $\mathrm{SO}_{4}^{\bullet-}$ and ${ }^{\bullet} \mathrm{OH}$ are for degrading organic contaminants, their widespread application to wastewater has been limited by the presence of radical 
quenchers, such as some inorganic anions and naturally-occurring organic compounds $[4,5]$. However, many recent articles also indicate that singlet oxygen $\left({ }^{1} \mathrm{O}_{2}\right.$, a non-radical reactive oxidizing species) can be produced for pollutants degradation via a non-radical process instead of radical attacking pathways [6]. Compared to $\mathrm{SO}_{4}{ }^{\bullet-}$ and ${ }^{\bullet} \mathrm{OH},{ }^{1} \mathrm{O}_{2}$ shows higher selectivity to electron-rich organics because of its electrophilic nature [7-9]. This advantage is conducive to the degradation of micropollutants, such as pharmaceuticals and endocrine-disrupting compounds (EDCs), in the coexistence of salinity and other organic matter.

The other well-known method for ${ }^{1} \mathrm{O}_{2}$ generation is photosensitized excitation of molecular oxygen. Photosensitizers including dyes, porphyrins, transition metal complexes and semiconductors act as the medium by transferring the light energy to ground dioxygen [10]. Other approaches to form ${ }^{1} \mathrm{O}_{2}$ involve the use of chemicals like potassium perchromate [11], ozonide [12], $\mathrm{H}_{2} \mathrm{O}_{2}$-hypochlorous [13], periodate [14], and bismuth oxides [15]. But these processes have to use toxic sensitizers or consume too much bismuth precursors. As an alternative, activating PDS/PMS is a feasible and green chemical process for ${ }^{1} \mathrm{O}_{2}$ production.

Current studies suggest that catalyst is influential to regulate the oxidizing species formed during PDS/PMS-based AOPs. For example, ${ }^{1} \mathrm{O}_{2}$ has been frequently found as the primary reactive species by using carbonaceous catalysts in PDS and PMS activation [16], but $\mathrm{SO}_{4}{ }^{\bullet-}$ and ${ }^{\bullet} \mathrm{OH}$ are usually found to be the dominant species when PDS/PMS are activated by homogeneous heat, $\mathrm{UV}$, and transition metals [3,17]. The difference between PDS and PMS leads to different activation pathways. In particular, a study by Wang and others indicated that $\mathrm{SO}_{4}{ }^{\bullet-}$ was mainly formed during $\mathrm{MnO}_{2}$-induced activation of PMS [18], but ${ }^{1} \mathrm{O}_{2}$ was evolved when PMS was replaced by PDS [19]. Given the increasing interest in PDS/PMS, some recent works have reviewed the application of PDS/PMS-based AOPs for water treatment $[2-4,17,20,21]$. Most of these reviews focus on the generation of $\mathrm{SO}_{4}{ }^{\bullet-}$, however, a comprehensive assessment of ${ }^{1} \mathrm{O}_{2}$ formation during PDS/PMS activation is rarely reported.

The present study reviews recent progress of ${ }^{1} \mathrm{O}_{2}$ formation in PDS/PMS activating systems. A brief introduction of the chemistry of ${ }^{1} \mathrm{O}_{2}$, performance of various types of catalysts, and insights into the possible mechanisms are critically discussed here. Finally, the research barriers and future perspectives are summarized in the last part. This review will provide more guidance for future research of PDS/PMS activation for water purification.

\section{Chemical Feature of ${ }^{1} \mathrm{O}_{2}$ and Its Oxidation}

Singlet oxygen $\left({ }^{1} \mathrm{O}_{2}\right)$ is the excited molecular oxygen, and broadly refers to two lowlying states oxygen species $\mathrm{O}_{2}\left({ }^{1} \Delta_{\mathrm{g}}\right)$ and $\mathrm{O}_{2}\left({ }^{1} \Sigma_{\mathrm{g}}{ }^{+}\right)$. Due to its short lifetime $\left(10^{-12} \mathrm{~s}\right), \mathrm{O}_{2}$ $\left({ }^{1} \Sigma_{\mathrm{g}}+\right)$ is easily converted to lower excited $\mathrm{O}_{2}\left({ }^{1} \Delta_{\mathrm{g}}\right)$ (lifetime $10^{-3}-10^{-6} \mathrm{~s}$ ) [22]. Herzberg first defined this excited oxygen with higher energy as ${ }^{1} \mathrm{O}_{2}$, but its importance was not recognized until 1964 when scientists established its role in chemical oxidation [23]. ${ }^{1} \mathrm{O}_{2}$ is a non-radical species with energy of $94.2 \mathrm{~kJ}$ per mole above ground-state molecular oxygen. As a mild oxidizing species, its standard redox potential $\left(\mathrm{E}^{0}=1.52 \mathrm{~V}\right)$ is significantly lower than that of ${ }^{\bullet} \mathrm{OH}\left(\mathrm{E}^{0}=2.8 \mathrm{~V}\right)$ and $\mathrm{SO}_{4}{ }^{\bullet-}\left(\mathrm{E}^{0}=2.5-3.1 \mathrm{~V}\right)[24,25]$. The generation of ${ }^{1} \mathrm{O}_{2}$ has been reported in a relatively broad $\mathrm{pH}$ range by various approaches (Figure 2a) including: (1) photosensitized excitation of triplet dioxygen [10,26]; (2) reaction of $\mathrm{H}_{2} \mathrm{O}_{2}$ with $\mathrm{NaClO}$ [13]; (3) released from phosphite ozonides, bismuth oxides and some organic peroxides [12,15]; (4) proper activation of inorganic oxidants, such as PDS/PMS and periodate $[7,14,27]$.

Due to its specific characteristics, ${ }^{1} \mathrm{O}_{2}$ has been applied in organic synthesis by selective oxidation [28], aqueous pollutant degradation [7], pathogenic bacteria inactivation [29] and medical cancer therapy [30]. The involvement of ${ }^{1} \mathrm{O}_{2}$ in these fields can be monitored by mainly three approaches including chemical probing tests, electron paramagnetic resonance (EPR) spectrometry and also chemiluminescence detection. Sodium azide $\left(\mathrm{NaN}_{3}\right)$ and furfuryl alcohol (FFA) are two popular ${ }^{1} \mathrm{O}_{2}$ quenchers. The reaction rate of ${ }^{1} \mathrm{O}_{2}$ with $\mathrm{NaN}_{3}$ 
and FFA have been tested to be $1 \times 10^{9} \mathrm{M}^{-1} \bullet \mathrm{s}^{-1}$ and $1.2 \times 10^{8} \mathrm{M}^{-1} \bullet \mathrm{s}^{-1}$, respectively [19]. However, ${ }^{1} \mathrm{O}_{2}$ is not sensitive to alcohols, such as methanol, ethanol and tert-butanol, which are normally used for $\mathrm{SO}_{4}{ }^{--}$and $\bullet$ OH quenching. Therefore, the presence of ${ }^{1} \mathrm{O}_{2}$ can be identified by using different chemical quenchers as indicated in Figure $2 \mathrm{~b}$. Moreover, ${ }^{1} \mathrm{O}_{2}$ can be captured by a spin trapping agent, 2,2,6,6-tetramethyl-4-piperidinol (TEMP), to form 2,2,6,6-tetramethyl-4-piperidone-N-oxyl (TEMPO) which could be detected by EPR with an intensive 1:1:1 signal (Figure 2c) [31]. In addition, direct or indirect chemiluminescence is also effective for the detection of ${ }^{1} \mathrm{O}_{2}$. For example, ${ }^{1} \mathrm{O}_{2}$ could be measured by solid-state near infrared spectroscopy at $1270 \mathrm{~nm}$, which is the radiative photon released from ${ }^{1} \mathrm{O}_{2}$ because of its intrinsic energy difference compared to ground state oxygen [32]. Fluorescence detection is another helpful technique for ${ }^{1} \mathrm{O}_{2}$ detection. Yuan et al. reported a conjugated probe consisting of a photosensitizer and a fluorogenic dye that were linked by aminoacrylate (AA) [33]. By reacting with ${ }^{1} \mathrm{O}_{2}$, the AA linker was cleaved and the probe divided to yield green fluorescence.

As an excited oxygen species, ${ }^{1} \mathrm{O}_{2}$ shows high affinity for electrophilic oxidation of electron-rich compounds with unsaturated $\mathrm{C}=\mathrm{C}$ bonds as well as sulfide and amine groups. This natural utility endows ${ }^{1} \mathrm{O}_{2}$ with the capability to selectively degrade pharmaceutical pollutants. Zhou et al. investigated the degradation of sulfamethoxazole by ${ }^{1} \mathrm{O}_{2}$, and found that sulfanilic group rather than isoxazole ring was the attack site [34]. Electron transfer and formation of endoperoxide intermediate were possible pathways involved in the ${ }^{1} \mathrm{O}_{2}$ induced sulfamethoxazole oxidation, specifically resulting in hydroxylation of the aniline ring, amine oxidation and oxidative coupling of the two intermediates (Figure 2d). Gao et al. discovered that the piperazinyl, oxazinyl and carboxylic substituents of ofloxacin were prone to be attacked by ${ }^{1} \mathrm{O}_{2}$ in the $\mathrm{LaBO}_{3} / \mathrm{PMS}$ reaction system [8]. Hydroxyl addition, $\mathrm{C}-\mathrm{N}$ cleavage, demethylation and decarboxylation were possible degradation pathways for ${ }^{1} \mathrm{O}_{2}$-mediated oxidation of ofloxacin (Figure 2d). Liu et al. found that the olefinic bonds and $\mathrm{C}-\mathrm{N}$ bonds of carbamazepine were susceptible to electrophilic ${ }^{1} \mathrm{O}_{2}$ oxidation during PMS activation with N-doped carbon fiber aerogel [9].

An earlier study indicated that the interaction between chlorophenols and PMS would produce $\mathrm{SO}_{4}{ }^{\bullet-},{ }^{\bullet} \mathrm{OH}$ as well as ${ }^{1} \mathrm{O}_{2}$, which then react with phenols or chlorophenols to generate hydroperoxides, and the later intermediate could dehydrate with the formation of p-benzoquinone (Figure 1) [35]. Under alkaline conditions, the reaction rate of ${ }^{1} \mathrm{O}_{2}$ toward dissociated chlorophenols is in the range of $1.60 \times 10^{8} \mathrm{M}^{-1} \cdot \mathrm{s}^{-1}$ to $1.93 \times 10^{8}$ $\mathrm{M}^{-1} \bullet \mathrm{s}^{-1}$, which can be slightly influenced by substitutes. In addition, organic sulfides and disulfides were reported to be oxidized to sulfoxides and thiolsulfinates, respectively [10]. Charge transfer and radical propagation were suggested as the two main mechanisms for ${ }^{1} \mathrm{O}_{2}$ oxidation. However, it should be noted that ${ }^{1} \mathrm{O}_{2}$ is not as strong as radicals of $\mathrm{SO}_{4}{ }^{\bullet-}$ and ${ }^{\bullet} \mathrm{OH}$ for the depletion of wastewater COD or TOC [36]. Given its antiinterference and selective feature, ${ }^{1} \mathrm{O}_{2}$ is frequently studied for tumor cell inactivation via protein oxidation [37].

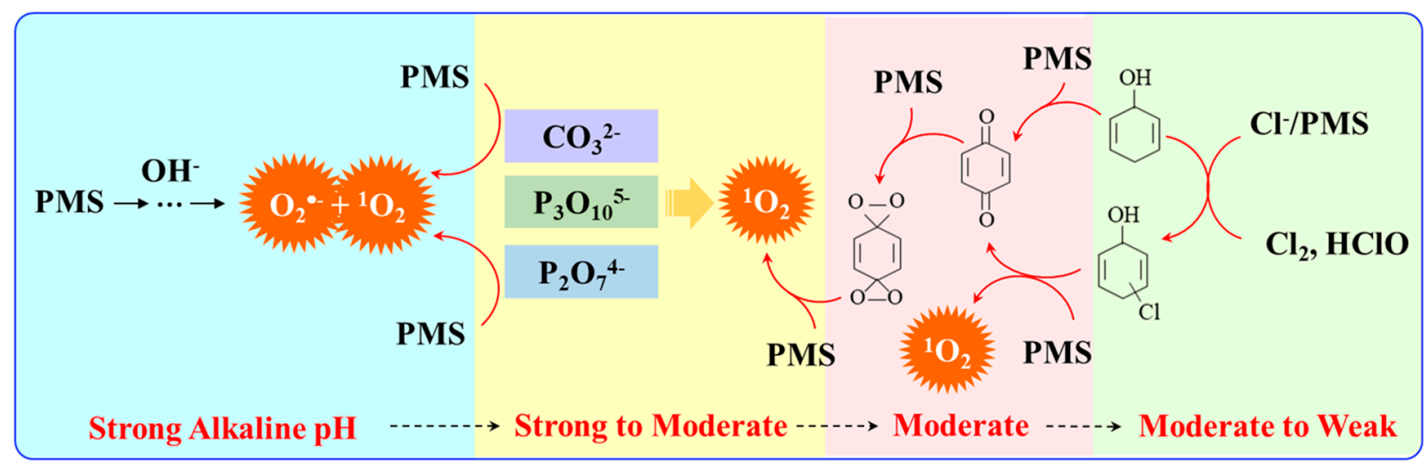

Figure 1. Evolution of ${ }^{1} \mathrm{O}_{2}$ in homogeneous activation systems requiring different alkaline conditions. 

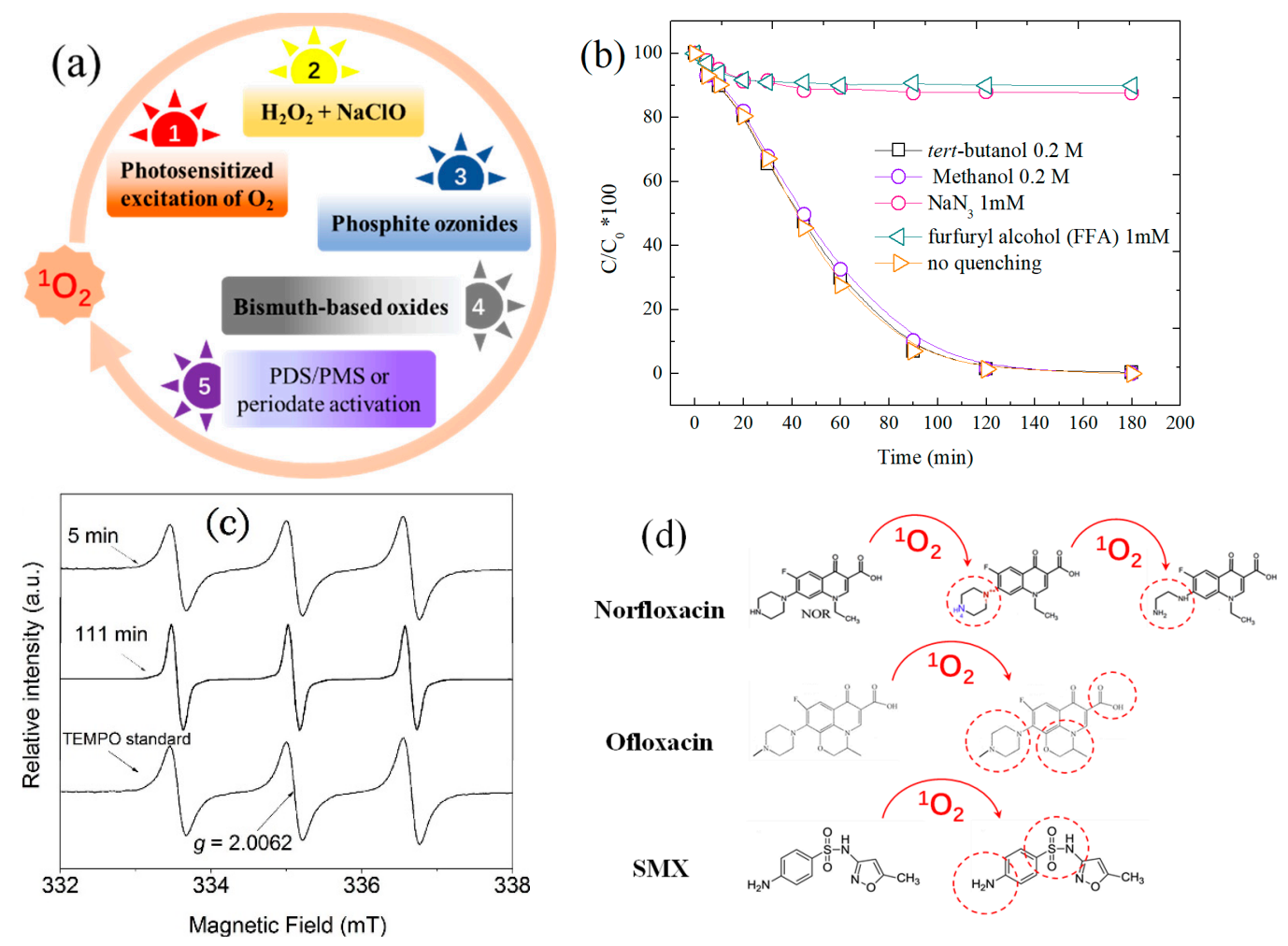

Figure 2. (a) Reported pathways of ${ }^{1} \mathrm{O}_{2}$ evolution; (b) the quenching effect of ${ }^{1} \mathrm{O}_{2}$ on phenol degradation with $\beta-\mathrm{MnO}_{2}$ (data reorganized from [19]); (c) EPR characteristic spectrum of TEMP-1 $\mathrm{O}_{2}$ (figure reprinted from [31]). The EPR spectrometer settings were as follows: modulation frequency, $100 \mathrm{kHz}$; modulation width, $0.079 \mathrm{mT}$; scanning field, $335 \pm 10 \mathrm{mT}$; amplitude: 2-500; time constant, 0.1-0.3 s; sweep time, $4 \mathrm{~min}$; microwave power, $4 \mathrm{~mW}$; and microwave frequency, $9.41 \mathrm{GHz}$; (d) oxidation pathways of some emerging contaminants by ${ }^{1} \mathrm{O}_{2}[8,34,38]$, reprinted with permission from Elsevier.

\section{Evolution of ${ }^{1} \mathrm{O}_{2}$ by Activating PDS/PMS in Homogenous Systems}

Although thermo-, UV- and alkali- catalytic activation have proven to be effective for both PDS and PMS, most of these homogeneous systems degrade organic contaminants by forming free radicals, such as $\mathrm{SO}_{4}{ }^{\bullet-}$ or ${ }^{\bullet} \mathrm{OH}$. Instead, as indicated in Table 1, the evolution of ${ }^{1} \mathrm{O}_{2}$ has been recently discovered when PMS was activated by quinones, phenols, alkali, etc.

Ketones, quinones, and phenols exist ubiquitously in water and soils. Studies have found that these hydrocarbons can activate PMS, and further suggested that ${ }^{1} \mathrm{O}_{2}$ might be the main oxidizing species. In 1974, Montgomery discovered that the decomposition rate of PMS was substantially proportional to the amount of ketone at low range of concentrations [39]. Lange and Brauer further verified that ${ }^{1} \mathrm{O}_{2}$ was formed during ketonecatalyzed PMS activation by using infrared phosphorescence [40]. Similar to ketones with carbonyl groups, Zhou et al. found that benzoquinone (BQ) could effectively activate PMS to degrade sulfamethoxazole, and the degradation rate increased as solution $\mathrm{pH}$ increased from 7 to 10 [41]. Radical trapping tests indicated that ${ }^{1} \mathrm{O}_{2}$ rather than $\mathrm{SO}_{4}{ }^{\bullet-}$ and ${ }^{\bullet} \mathrm{OH}$ was produced in the BQ/PMS system. The proposed mechanism for BQ-mediated activation of PMS, as illustrated in Figure 1, can be described by Equations (1)-(4). Firstly, PMS anions are added to the carbonyl group of $B Q$ via nucleophilic attack and converted to peroxide adduct labeled as intermediate I as shown in Equation (1). Under alkaline conditions, intermediate I undergoes dehydrogenation and forms intermediate II (Equation (2)), which is further transformed into dioxirane (intermediate III, Equation (3)). Finally, the dioxirane reacts with ionized PMS at a stoichiometric ratio of $1: 2$, producing ${ }^{1} \mathrm{O}_{2}$ and $\mathrm{BQ}$ again (Equation (4)). It is noteworthy that, as stated by Gallopo et al., dioxirane can be formed as a key intermediate during the reaction between PMS and ketones or $\mathrm{BQ}$ through ${ }^{18} \mathrm{O}$ labeling 
and kinetic studies [42]. Zhang et al. further detected dioxirane and ${ }^{1} \mathrm{O}_{2}$ by using droplet spray ionization mass spectrometry (DSI-MS) as well as oxygen isotope analysis [43].

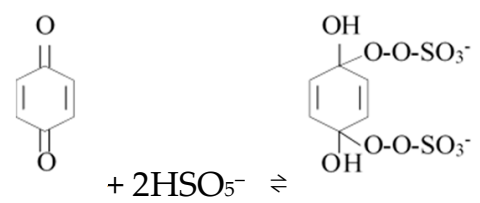

intermediate I

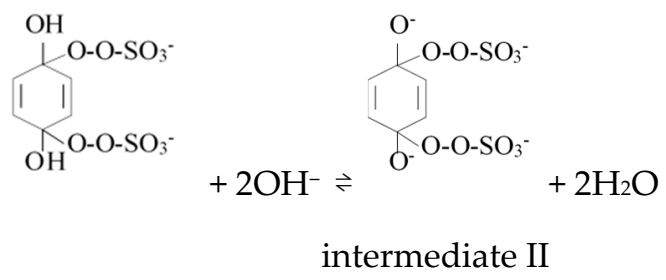

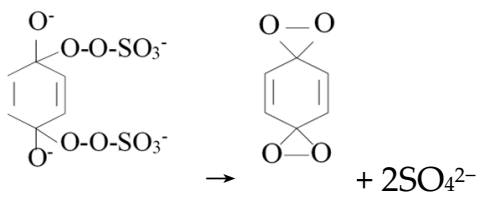

intermediate II

intermediate III<smiles>OC12C=CC3(OO3)OC1O2</smiles><smiles>O=C1C=CC(=O)C=C1</smiles>

intermediate III

Apart from ketones and quinones, phenols are reactive enough to activate PMS because the phenolic group is easily oxidized to quinone byproducts. Zhou et al. found that PMS could be effectively activated to produce ${ }^{1} \mathrm{O}_{2}$ by phenol at $\mathrm{pH} 8.5$ and 10 , in which phenol was oxidized to benzoquinone to promote PMS activation [34]. The chemical structure of phenols is a critical influencing factor for the overall reaction because the substituents and their positions on phenol could remarkably affect the yield of quinone intermediates. At acidic $\mathrm{pH}$, phenols are poorly dissociated so that they can hardly form intramolecular complex with ionized PMS in such molecular state. Therefore, phenols are more likely to react with PMS in alkaline conditions [35]. In addition, it should be noted that the reaction between chloride and PMS at acidic $\mathrm{pH}$ would generate reactive chlorine species such as $\mathrm{Cl}_{2}$ and $\mathrm{HClO}$, and further led to organic chlorination. But this undesirable side reaction was highly inhibited because ${ }^{1} \mathrm{O}_{2}$ was mainly produced at alkali $\mathrm{pH}$ so that chloride showed negligible effect on phenol transformation [44].

In fact, alkali is a typical homogeneous PDS/PMS catalyst, and has been employed for in situ field remediation. The activation of PDS by alkali generates $\mathrm{SO}_{4}{ }^{\bullet-}, \bullet^{\bullet} \mathrm{OH}$ and superoxide $\left(\mathrm{O}_{2}{ }^{\bullet-}\right)$. Unlike PDS, the activation of PMS by alkali initiates non-radical attack for contaminants degradation. Qi et al. found that alkali can activate PMS at ambient temperature to generate $\mathrm{O}_{2}{ }^{\bullet-}$ and ${ }^{1} \mathrm{O}_{2}$ for oxidative degradation of acid orange 7 (AO7) [45]. At lower $\mathrm{NaOH}$ concentrations $(0.6-1.0 \mathrm{mM})$, both $\mathrm{O}_{2}{ }^{\bullet-}$ and ${ }^{1} \mathrm{O}_{2}$ were formed, but only $\mathrm{O}_{2}{ }^{\bullet-}$ was generated at higher doses of $\mathrm{NaOH}(8.0 \mathrm{mM})$. It was proposed that $\mathrm{O}_{2}{ }^{\bullet-}$ formed and then recombined to generate one ${ }^{1} \mathrm{O}_{2}$ and one hydrogen peroxide. But under extremely high $\mathrm{pH}$ conditions, the transformation of $\mathrm{O}_{2}{ }^{\bullet-}$ to ${ }^{1} \mathrm{O}_{2}$ was suppressed when the $\mathrm{pH}$ was higher than the $\mathrm{pK}_{\mathrm{a}}$ of $\mathrm{O}_{2}{ }^{\bullet-}$ as indicated by Equation (5) [46]. It was worth noting that 
in the studies from Qi [45] and Lou [47], the addition of p-BQ completely inhibited the oxidation reaction in the PMS/base system. But Zhou's report pointed out that $\mathrm{p}$-BQ could effectively activate PMS to generate ${ }^{1} \mathrm{O}_{2}$ under alkaline conditions [41]. Thus the role of $\mathrm{p}-\mathrm{BQ}$ in PMS activation might be closely related to its dose and $\mathrm{pH}$ conditions:

$$
2 \mathrm{O}_{2} \cdot-+2 \mathrm{H}^{+} \rightarrow \mathrm{H}_{2} \mathrm{O}_{2}+{ }^{1} \mathrm{O}_{2}
$$

Table 1. Performance and mechanism for PDS/PMS oxidation of pollutants in typical homogenous systems.

\begin{tabular}{|c|c|c|c|c|c|}
\hline Systems & Target/Pollutant & $\begin{array}{c}\text { Degradation Rate } \\
\text { and Time }\end{array}$ & $\begin{array}{l}\text { Radicals } \\
\text { Involve }\end{array}$ & $\begin{array}{l}\text { Active Catalytic } \\
\text { SitesOr Activation } \\
\text { Mechanism }\end{array}$ & References \\
\hline phenols/PMS & sulfamethoxazole & $\begin{array}{c}100 \% \text { in } 60 \text { min at } \\
\text { pH } 10\end{array}$ & ${ }^{1} \mathrm{O}_{2}$ & $\begin{array}{l}\text { quinone } \\
\text { intermediates } \\
\text { formed from } \\
\text { phenolic parents }\end{array}$ & Zhou et al. [34] \\
\hline PMS & chlorophenols & $\begin{array}{l}65 \% \text { of } 4-\mathrm{CP}, 70 \% \\
\text { of } 2,4-\mathrm{DCP} \text { and } \\
95 \% \text { of } 2,4,6-\mathrm{TCP} \\
\text { in } 60 \mathrm{~min} \text { at } \mathrm{pH} 9\end{array}$ & 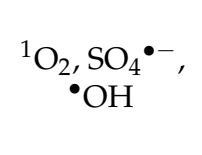 & chlorophenols & Li et al. [35] \\
\hline ketones/PMS & / & 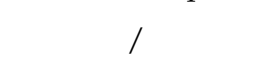 & ${ }^{1} \mathrm{O}_{2}$ & ketone carbonyl & $\begin{array}{l}\text { Lange and } \\
\text { Brauer [40] }\end{array}$ \\
\hline benzoquinone/PMS & sulfamethoxazole & $\begin{array}{c}86 \% \text { in } 3 \text { min at } \\
\text { pH } 10\end{array}$ & ${ }^{1} \mathrm{O}_{2}$ & quinone carbonyl & Zhou et al. [41] \\
\hline benzoquinone/PMS & / & l & ${ }^{1} \mathrm{O}_{2}$ & $\begin{array}{l}\text { quinone carbonyl } \\
\mathrm{Cl}^{-} \text {interact with }\end{array}$ & Zhang et al. [43] \\
\hline $\mathrm{Cl}^{-} /$phenol/PMS & phenols & $\begin{array}{c}100 \% \text { in } 60 \text { min at } \\
\text { pH } 10\end{array}$ & ${ }^{1} \mathrm{O}_{2}$ & $\begin{array}{l}\text { PMS to form } \\
\text { chlorophenols and } \\
\text { benzoquinone }\end{array}$ & Li et al. [44] \\
\hline base/PMS & acid orange 7 & $90 \%$ in $60 \mathrm{~min}$ & ${ }^{1} \mathrm{O}_{2}, \mathrm{O}_{2} \bullet-$ & $\begin{array}{l}\mathrm{O}_{2}{ }^{\bullet-} \text { intermediates } \\
\text { for }{ }^{1} \mathrm{O}_{2} \text { generation } \\
\text { under too much } \mathrm{pH} \\
\text { conditions }\end{array}$ & Qi et al. [45] \\
\hline $\begin{array}{c}\text { base/polyphosphates/ } \\
\text { PMS }\end{array}$ & acid orange 7 & $100 \%$ in $500 \mathrm{~s}$ & ${ }^{1} \mathrm{O}_{2}, \mathrm{O}_{2} \bullet-$ & remains unclear & Luo et al. [47] \\
\hline $\mathrm{BO}_{2}{ }^{-} / \mathrm{PMS}$ & acid red 1 & $97.8 \%$ in $10 \mathrm{~min}$ & ${ }^{1} \mathrm{O}_{2}$ & $\begin{array}{l}\text { nucleophilic } \\
\text { mechanisms }\end{array}$ & Rao et al. [48] \\
\hline $\mathrm{CO}_{3}{ }^{2-} / \mathrm{PMS}$ & acid orange 7 & $100 \%$ in $40 \mathrm{~min}$ & ${ }^{1} \mathrm{O}_{2}, \mathrm{O}_{2} \bullet-$ & $\begin{array}{c}\text { PMS } \\
\text { self-decomposition, } \\
\mathrm{O}_{2}{ }^{\bullet-} \text { intermediates } \\
\text { by base-catalyzed } \\
\text { hydrolysis for }{ }^{1} \mathrm{O}_{2} \\
\text { generation }\end{array}$ & Nie et al. [49] \\
\hline $\mathrm{Cl}^{-} / \mathrm{PMS}$ & $\begin{array}{c}2,4- \\
\text { dimethylphenol }\end{array}$ & $100 \%$ in $20 \mathrm{~min}$ & $\begin{array}{l}\mathrm{SO}_{4}^{\bullet-},{ }^{\bullet} \mathrm{OH}, \\
{ }^{1} \mathrm{O}_{2}, \mathrm{Cl}^{\bullet}\end{array}$ & / & Wang et al. [50] \\
\hline $\mathrm{Cl}^{-} / \mathrm{PMS}$ & methylene blue & $100 \%$ in $120 \mathrm{~min}$ & ${ }^{1} \mathrm{O}_{2}, \mathrm{Cl}^{\bullet}$ & $\begin{array}{c}\text { PMS } \\
\text { self-decomposition, } \\
\text { reactive chlorine }\end{array}$ & Yang et al. [51] \\
\hline
\end{tabular}

Base activation normally requires continuous addition of alkali to maintain desirable $\mathrm{pH}$ value. Instead, some studies have developed new effective homogeneous activators, such as chloride, carbonate and $\mathrm{BO}_{2}{ }^{-}$as shown in Figure 1. For example, Lou et al. used polyphosphates to enhance the alkali activation of PMS, in which both $\mathrm{O}_{2}{ }^{\bullet-}$ and ${ }^{1} \mathrm{O}_{2}$ were detected as the main ROSs [47]. Polyphosphates are nucleophiles which promote the breakage of the peroxide $\mathrm{O}-\mathrm{O}$ bond to speed up ${ }^{1} \mathrm{O}_{2}$ formation. Like polyphosphate, $\mathrm{BO}_{2}{ }^{-}$ is also a nucleophile $(\mathrm{Nu})$ which can bond with PMS to generate a $\mathrm{NuOH}^{+}$intermediate, and then convert into ${ }^{1} \mathrm{O}_{2}$ with excellent anti-interference performance [48]. Moreover, Nie et al. found that $\mathrm{CO}_{3}{ }^{2-}$ could activate PMS for the degradation of pharmaceuticals, 
phenols and dyes [49]. Species like ${ }^{1} \mathrm{O}_{2}$ and $\mathrm{O}_{2}{ }^{\bullet-}$ were identified, and the system showed good resistance toward the interference of $\mathrm{Cl}^{-}, \mathrm{NO}_{2}{ }^{-}, \mathrm{HCO}_{3}{ }^{-}$and humic acid.

Chloride is another promoter for PMS activation under both acid and alkaline conditions. Wang et al. used the $\mathrm{Cl}^{-} / \mathrm{PMS}$ process for the treatment of coking wastewater concentrate, in which ${ }^{1} \mathrm{O}_{2}$, hypochlorous acid and chlorine radicals were identified [50]. They discovered that the efficiency of the PMS $/$ base $/ \mathrm{Cl}^{-}$system was vastly influenced by the dosage of $\mathrm{Cl}^{-}$and $\mathrm{NaOH}$ [51]. The degradation of model pollutant was remarkably enhanced by $\mathrm{Cl}^{-}$at low alkalinity, but inhibited when $\mathrm{NaOH}$ concentration was up to $2 \mathrm{mM}$. High alkalinity reduced the formation of organic halides in the PMS $/ \mathrm{base} / \mathrm{Cl}^{-}$ reaction system, which would be significant for the treatment of saline wastewater.

\section{Evolution of ${ }^{1} \mathrm{O}_{2}$ by Activating PDS/PMS with Metal-Free Carbon Catalysts}

Metal-free carbon-based materials (MFCMs) are emerging heterogeneous catalysts for PDS/PMS-based oxidation processes in recent years. They have received much attention because of their attractive advantages over metal-based catalysts, such as less cost, no secondary pollution, and their chemical, thermal and mechanical stabilities. MFCMs including reduced graphene oxide (GO), carbon nanotubes (CNTs), nano-diamonds (NDs), carbon spheres (CS) and biochar in different sizes and specifications are investigated as potential PMS/PDS catalysts [16]. Unlike metal-catalyzed processes, organic pollutants can be removed via not only catalytic degradation but also adsorption by MFCMs.

To date, both radical and non-radical oxidations have been reported for MFCMsmediated PMS/PDS AOPs (Table 2) [16,21]. The non-radical pathway is a potential route to resolve the influence of background organic and inorganic matters on the degradation of targeted pollutants. In a non-radical reaction system, MFCMs can serve as medium for electron transfer between PMS/PDS and organic pollutants. As listed in Figure 3a and Table 2, there are different active sites involved in activating PMS for ROSs generation. They include: (i) delocalized $\pi$-electrons (C- $\pi$ ) [52]; (ii) structural defects and vacancies [53]; (iii) heteroatoms bonded to carbon in the form of $\mathrm{C}=\mathrm{N}-\mathrm{C}$ and $\mathrm{N}-(\mathrm{C})_{3}$ [54]; and (iv) $\mathrm{C}=\mathrm{O}$ and pyran-like oxygen functional groups [55] produced at vacancy defective edges (Equations (6)-(12)):

$$
\begin{aligned}
& \mathrm{HSO}_{5}{ }^{-}+\mathrm{C}-\pi \rightarrow \mathrm{SO}_{4}{ }^{\bullet-}+\mathrm{OH}^{-}+\mathrm{C}-\pi^{+} \\
& \mathrm{HSO}_{5}{ }^{-}+\mathrm{C}-\pi^{+} \rightarrow \mathrm{SO}_{5}{ }^{-}+\mathrm{H}^{+}+\mathrm{C}-\pi \\
& \mathrm{HSO}_{5}{ }^{-}+\mathrm{C}=\mathrm{C}=\mathrm{O} \rightarrow \mathrm{SO}_{4}{ }^{--}+\mathrm{OH}^{-}+\mathrm{C}=\mathrm{C}-\mathrm{O}^{+} \\
& \mathrm{HSO}_{5}{ }^{-}+\mathrm{C}=\mathrm{C}-\mathrm{O}^{+} \rightarrow \mathrm{SO}_{5}{ }^{-}+\mathrm{H}^{+}+\mathrm{C}=\mathrm{C}=\mathrm{O} \\
& \mathrm{HSO}_{5}{ }^{-}+\mathrm{C}=\mathrm{N}-\mathrm{C}^{+} \rightarrow \mathrm{SO}_{5}{ }^{\bullet-}+\mathrm{H}^{+}+\mathrm{C}-\mathrm{N}-\mathrm{C} \\
& \mathrm{SO}_{5}{ }^{\bullet-}+\mathrm{SO}_{5}{ }^{\bullet-} \rightarrow 2 \mathrm{SO}_{4}{ }^{2-}+{ }^{1} \mathrm{O}_{2} \\
& \text { [PDS/PMS }]+\left[\mathrm{sp}^{2} / \mathrm{sp}^{3} \text {-moieties }\right] \rightarrow \text { non-radical / free-radical }
\end{aligned}
$$

However, since most MFCMs are constructed with multiple structure and surface characteristics, the identification of the intrinsic active site remains difficult and controversial.

\subsection{Carbon Nanotubes (CNTs)}

CNTs are one dimensional quantum wires fabricated by rolling 2D graphite sheets. CNTs belong to the family of fullerene, and consist of $\mathrm{sp}^{2}$-hybridized atomic carbon in a hexagonal network. Based on their structural differences, there are single-walled CNTs (SWCNTs) and multi-walled CNTs (MWCNTs). With excellent adsorptive ability and electron conductivity, CNTs can act as good electron shuttle between organic pollutants and persulfate oxidants [56] so both CNTs-mediated electron transfer from organics to persulfate and ${ }^{1} \mathrm{O}_{2}$ are responsible for a nonradical degradative route [57]. Yun et al. explored the role of PDS during its activation with $\mathrm{nFe}^{0}$ and CNTs [58]. Their results indicated that the radical oxidation process was dominant in the $\mathrm{nFe}^{0} / \mathrm{PDS}$ system but a non-radical 
mechanism was discovered in the CNTs/PDS system. Further chronoamperometric tests revealed that CNTs served as electron bridge for PDS and organic pollutants.

Noteworthily, the presence of different oxygen functional groups (OFGs) available on the surface of CNTs also play an important role because they directly influence the zeta potential of CNTs [59]. The removal of oxygen contents, especially the blockage of carboxylate group $(-\mathrm{COOH})$ reduction to other carbonyl $(\mathrm{C}=\mathrm{O})$ and hydroxyl $(-\mathrm{OH})$ groups through a annealing route is recommended to increase the zeta potential of CNTs. Consequently, this will facilitate the adsorptive uptake of PDS because of weaker electrostatic repulsion, and favor non-radical oxidation route of the targeted pollutants. PDS hydrolysis catalytically occurs when PDS complex with CNTs, and the surface nucleophilic $\mathrm{C}=\mathrm{O}$ was found to be the crucial sites for the generation of $\mathrm{O}_{2}{ }^{\bullet-}$ [60]. The produced $\mathrm{O}_{2}{ }^{\bullet-}$ then recombines and is finally converted to ${ }^{1} \mathrm{O}_{2}$ with the production of hydrogen peroxide as well.

In other cases, surface N-doped CNTs were also investigated compared to pristine material. Sun et al. reported that CNTs doped with 0.88 at.\% of nitrogen could achieve a better efficiency (as high as 7-fold) than pristine CNTs for catalytic PMS oxidation of phenol, but showed decreased efficiency on PDS activation. Free sulfate radicals were discovered to be responsible for phenol degradation in the same study [61]. However, some researchers also obtained a contrasting result that non-radical oxidation was dominant in the N-CNTs/PMS system [62]. Because of greater electronegativity, it was postulated that the doped $\mathrm{N}$ would enhance the interaction between the carbon atoms and PMS, and thus boost electron transfer.

\section{2. $\mathrm{GO} / \mathrm{rGO}$}

Graphene oxide $(\mathrm{GO})$ is a single-atomic layered carbon material laced with various oxygen-containing groups that fabricated by powerful oxidation of graphite. As a graphenebased material, GO and its reduced derivative rGO have shown great potential in the hydrophilic adsorption of organics and PMS/PDS catalysis, due to various structural defects, vacancies and $\mathrm{C}=\mathrm{O}$ functional groups [53]. As indicated by density functional theory (DFT) calculations, vacancies and defective edges of rGO would prolong the O-O bond of PMS molecules, enhance adsorption and direct electron transfer, thus facilitate final break-up of O-O bond to initiate nonradical oxidation [63].

The increase of carbonyl groups and graphitization degree would create more vacancies and defects to enhance the catalytic performance of GO/rGO [27]. A simple but effective strategy is to modulate rGO by heteroatom doping [64]. Carbon doped with $\mathrm{N}$ is expected to possess more lattice defects for regulating the electronic structure, such as $\mathrm{sp}^{2}$-hybridized carbon skeletons $[65,66]$. Kang et al. reported that $\mathrm{N}$-doping could significantly improve the activity of reduced graphene oxide (N-rGO) for PMS activation using urea as the nitrogen source [67]. It was found that pyridine $\mathrm{N}$, pyrrole $\mathrm{N}$, graphite $\mathrm{N}$, and oxidized $\mathrm{N}$ in $\mathrm{N}-\mathrm{rGO}$ catalyst accounted for $49.7 \%, 35.2 \%, 9.0 \%$, and $5.9 \%$, respectively (Figure $3 \mathrm{~b}$ ). ${ }^{\bullet} \mathrm{OH}, \mathrm{SO}_{4}{ }^{\bullet-}$ and ${ }^{1} \mathrm{O}_{2}$ were potential active species for pollutant degradation. As previous reported, pyrrolic $\mathrm{N}$ sites were important to adsorb and activate PMS to form ${ }^{1} \mathrm{O}_{2}$ [68]. Doping nitrogen into carbon matrix is not only beneficial to PMS adsorption due to the increase of surface basicity, but also facilitates electron transfer to the negatively charged PMS, thereby enhancing the catalytic activity. 

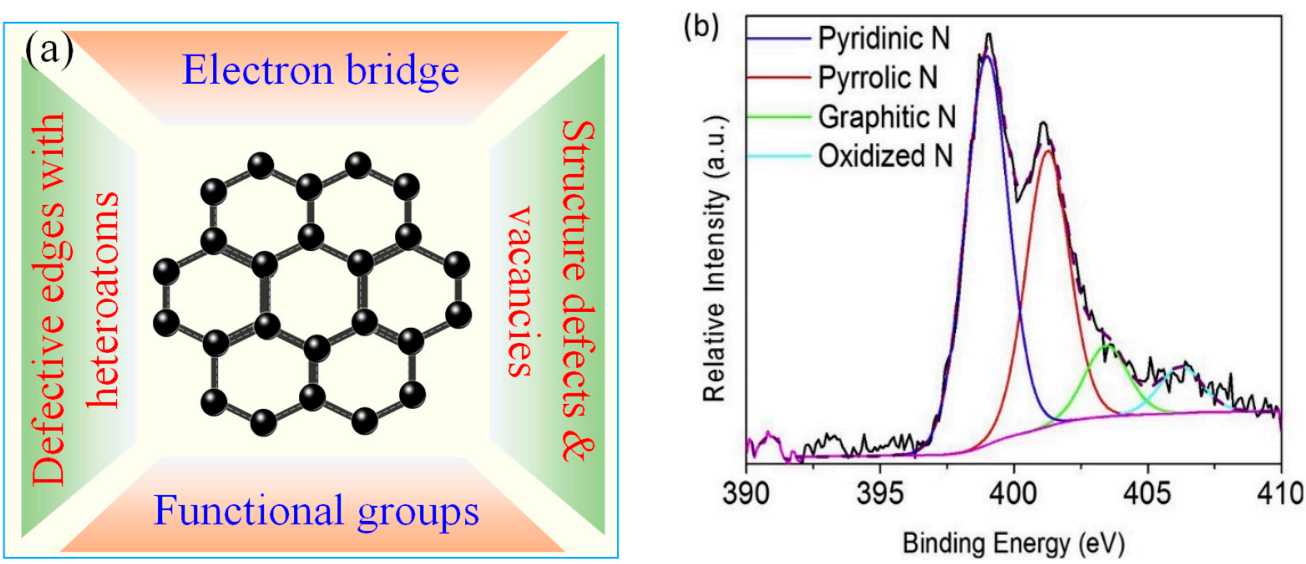

Figure 3. (a) The proposed active sites of MFCMs for ${ }^{1} \mathrm{O}_{2}$ evolution via catalytic PDS/PMS activation. (b) The XPS spectra of $\mathrm{N}$ 1s for doping $\mathrm{N}$ element in different states [67], reprinted with permission from Elsevier.

Besides, the co-doping of other heteroatoms also results in synergistic increase in catalytic performance to generate ROSs. Sun et al. introduced sulfur and nitrogen element into rGO to synthesize a catalyst named i-rGO-NS [69]. The XPS characterizations suggested that the additional sulfur doping increased the content of graphite $\mathrm{N}(33.74 \%)$ and change the distribution of $\mathrm{N}$ atom in RGO. Sulfur dopants existed in the form of thiophene $\mathrm{S}$ and oxidized S. Compared to rGO, i-rGO-N and metal catalysts, i-rGO-NS showed better reactivity to PMS oxidation of methyl p-hydroxybenzoate (MP). Quenching tests and EPR results indicated that ${ }^{1} \mathrm{O}_{2}$ was the dominant species but ${ }^{\bullet} \mathrm{OH}$ and $\mathrm{SO}_{4}{ }^{\bullet-}$ scarcely contributed to MP removal. In general, pyrrole $\mathrm{N}$ and pyridine $\mathrm{N}$ could activate the $\pi$ electrons of the $\mathrm{sp}^{2}$ carbon atoms on rGO, and induce the activation of PMS to produce $\mathrm{SO}_{4}{ }^{--}$, while graphite $\mathrm{N}$ could promote the transfer of electrons to PMS to generate ${ }^{1} \mathrm{O}_{2}$ by neighboring carbon atoms [70]. In addition, thiophene $\mathrm{S}$ could mediate the redistribution of charge density to promote the creation of ${ }^{1} \mathrm{O}_{2}$ [71]. Chen et al. reported that the sole $\mathrm{N}$-atom doping could interrupt the spin and charge dispersion of the uniform $\mathrm{sp}^{2}$-hybridized configuration, leading to graphene chemical inert. However, the co-doping of a second dopant $\mathrm{B}$-atom would activate carbon atoms adjoining to the $\mathrm{N}$-atom. This provided higher electron and spin density, which accelerated the PMS activation through non-radical mechanism [72].

In contrast, high temperature heating of carbon catalysts brings about challenges of poor material dispersion and hydrophilic-to-hydrophobic transformation. As an alternative solution, Zhang et al. anchored amino-functionalized mesoporous silica $\left(\mathrm{NH}_{2}-\mathrm{MCM}-41\right)$ to $\mathrm{N}$-doped GO materials (NG) to improve the hydrophilicity of NG materials, greatly improving the performance on simultaneous adsorption and degradation of contaminants [73]. The introduction of amino groups realized the inversion of negative charge to positive charge, enhanced the electrostatic interaction between the surface of NG and phenolic pollutants, and facilitated the removal of pollutants. Additionally, amino groups would increase the electron transfer capacity of NG to promote catalytic activation [74]. The mesoporous channel of $\mathrm{NH}_{2}-\mathrm{MCM}-41 / \mathrm{NG}$ provided effective transport and reaction units for PMS, pollutants and also ${ }^{1} \mathrm{O}_{2}$.

\subsection{Biochar}

Biochar is derived from biomass carbonization under an oxygen-free environment. Biochar is cheap and widely available, and functions as a way for carbon sequestration. In recent years, biochar has attracted significant attentions for PDS/PMS activation. Biomass type and pyrolysis temperature are important factors influencing the biochar structural features. For example, biochar obtained through high-temperature pyrolysis $\left(800{ }^{\circ} \mathrm{C}\right)$ have shown structural oxygen defects, which acted as electron conductor moieties for molecular $\mathrm{O}_{2}$ activation via non-radical routes [75]. This finding provided a novel approach to obtain 
biochar with vacancy defects capable of catalytic pollutants degradation through a nonradical pathway. Moreover, Huang et al. has explored the role of ketone structure of sludge-derived biochar [76]. The formation of ${ }^{1} \mathrm{O}_{2}$ was detected for the mineralization of BPA. It was deduced that creation of epoxy structure was a possible course to generate ${ }^{1} \mathrm{O}_{2}$ for ketone-catalyzed PMS decomposition as presented in Equations (13)-(16):

$$
\begin{aligned}
& \text { BC-RCOR }{ }^{*}+\mathrm{HSO}_{5}{ }^{-} \rightarrow \mathrm{BC}-\mathrm{RCOHR}{ }^{*}\left(\mathrm{O}-\mathrm{O}-\mathrm{SO}_{3}{ }^{-}\right) \\
& \text {BC- } \mathrm{RCOHR}^{*}\left(\mathrm{O}-\mathrm{O}-\mathrm{SO}_{3}{ }^{-}\right)+\mathrm{OH}^{-} \rightarrow \mathrm{BC}-\mathrm{RCO}^{-}-\mathrm{R}^{*}\left(\mathrm{O}-\mathrm{O}-\mathrm{SO}_{3}{ }^{-}\right)+\mathrm{H}_{2} \mathrm{O} \\
& \mathrm{BC}-\mathrm{RCO}^{-}-\mathrm{R}^{*}\left(\mathrm{O}-\mathrm{O}-\mathrm{SO}_{3}{ }^{-}\right) \rightarrow \mathrm{BC}-\mathrm{RCOOR}^{*}+\mathrm{SO}_{4}{ }^{2-} \\
& \mathrm{BC}-\mathrm{RCOOR}^{*}+\mathrm{SO}_{5}{ }^{2-} \rightarrow \mathrm{BC}-\mathrm{RCOR}^{*}+\mathrm{SO}_{4}{ }^{2-}+{ }^{1} \mathrm{O}_{2}
\end{aligned}
$$

Additionally, a recent study revealed the role of doped $\mathrm{N}$ and $\mathrm{S}$ for the catalytic activity of modified biochar [77]. The N-doped biochar gave a positive while S-doping demonstrated a negative effect on biochar-catalyzed PMS activation for metolachlor degradation. It was suggested that $\mathrm{N}$-doping would augment more positive charge of the neighboring $\mathrm{C}$ atoms to interact with negatively charged $\mathrm{HSO}_{5}{ }^{-}$species. However, in the case of S-doping, there was insignificant charge transfer due to the disruption of charge redistribution, which referred to breakage of charge balance in covalent carbon electron system. The synergistic effect of the heteroatom $\mathrm{N}$-doping and the prevailing structural defects of graphene both contributed to induce non-radical pathway for the catalytic PMS oxidation of phenol [78]. Yin et al. prepared N-doped sludge-derived biochar (SDBC) with similar Raman spectral characteristics to graphene oxide [79]. They discovered that SDBC could efficiently activate PDS for the removal of sulfamethoxazole through ${ }^{1} \mathrm{O}_{2}$-mediated degradation, in which $94.6 \%$ of sulfamethoxazole (SMX) and $58 \%$ of TOC were removed after 180 min of reaction. Furthermore, a high value of $\mathrm{I}_{\mathrm{d}} / \mathrm{I}_{\mathrm{g}}$ of SDBC indicated abundant amount of defect sites inside the carbon layer structure which were possible catalytic sites.

Regarding nitrogen tailing, sewage sludge usually contains $\mathrm{N}$ from microbial cells and can be utilized to produce low-N doped sludge biochar. Mian et al. investigated the effectiveness of chemically treated sludge-based biochar for the degradation of organic dyes [80]. It was disclosed that pyridinic- $\mathrm{N}$ active sites were the main contributor for the catalytic degradation through non-radical pathway, while pyrrolic-N, activated $\mathrm{C}^{(+)}$as well as surface area acted as active sites for the adsorptive uptake of the pollutants under consideration. Due to the remarkable role of doped N, some studies attempted to increase the $\mathrm{N}$ doping amount. Hu et al. doped nitrogen into sludge-derived biochar using urea as a supplementary N source [81]. BET tests and Raman spectroscopy unveiled that the addition of urea improved the specific surface area and the number of active sites for interaction with PMS. Compared to non-doped sludge biochar (C-700), the new N-doped catalyst NC-700 exhibited better activity to remove organic pollutants by synergistic effect of adsorption and catalytic PMS oxidation. The adsorption capacity of methylene blue (MB) on NC-700 reached $35.83 \mathrm{mg} / \mathrm{g}$ and the removal rate of MB in NC-700/PMS system was $98.7 \%$ after $20 \mathrm{~min}$. The chemical quenching and EPR tests clearly supported that large amount of ${ }^{1} \mathrm{O}_{2}$ but little ${ }^{\bullet} \mathrm{OH}$ and $\mathrm{SO}_{4}{ }^{\bullet-}$ were produced in the reaction system, affirming the non-radical pathway induced by biochar.

\subsection{Other MFCMs}

Many other MFCMs in different dimensions and structure also have shown good reactivity for PDS/PMS activation. Graphited nanodiamond (G-ND) demonstrated superior activation for both PMS and PDS when compared with other metal-free catalysts such as graphene, CNTs, graphite, and fullerene. For example, G-ND showed excellent catalytic performance in persulfate system for the mineralization of phenolic compounds and pharmaceuticals through non-radical pathway [82]. It was deduced from different analysis that G-ND provided surface binding sites for both PDS and phenol molecule to a close proximity. In the formed charge transfer complex, phenol acted as an electron 
donor and PDS served an electron acceptor, while G-ND functioned as a facile electron transfer mediator channel. Moreover, no inhibition was observed in the existence of oxidant scavengers as well as unwanted natural organic matters. Additionally, the temperature effect on the proportion of graphitic natural carbon in the $\mathrm{sp}^{2} / \mathrm{sp}^{3}$ configurations of NDs has been investigated in detail [83]. It was revealed that higher annealing temperature $\left(1100^{\circ} \mathrm{C}\right)$ treatment provided more graphitic shell than the lower annealing temperature $\left(900{ }^{\circ} \mathrm{C}\right)$. The NDs catalyst obtained at $1100{ }^{\circ} \mathrm{C}(\mathrm{S}-\mathrm{ND}-1100)$ contributed to non-radical oxidation route, but the NDs-based catalyst achieved at $900{ }^{\circ} \mathrm{C}$ provided radical-dominated oxidation route during PMS activation.

Typically, PDS and PMS were adsorbed and activated on a carbon surface [84]. Jiang et al. successfully developed a metal-free porous carbon aerogel (CA) through the hydrothermal carbonization route by using D-glucose, ammonium persulfate, and aniline [85]. The $\mathrm{sp}^{2}$-hybridized moieties available on CA surface would interact with PDS and dissociate the O-O bonds of PDS. Then the active complex acquired from the first stage initiated the oxidation of rhodamine $\mathrm{B}(\mathrm{RhB})$ directly via electron transfer mechanism without the generation of free radicals. In another study, both urea and $\mathrm{NaHCO}_{3}$ were used to functionalize chitosan-derived carbon nanosheets with graphene-like structures [86]. The as-obtained material reflected great potential for the oxidation of recalcitrant pollutants by activating PMS to produce ${ }^{1} \mathrm{O}_{2}$ as the main ROSs.

Table 2. Performance and mechanism of typical MFCMs catalysts for PDS/PMS oxidation of pollutants.

\begin{tabular}{|c|c|c|c|c|c|c|c|}
\hline Catalyst & Oxidant & Target Pollutant & Degrada & Rate and & $\begin{array}{c}\text { Radicals } \\
\text { Mechanism }\end{array}$ & $\begin{array}{c}\text { Active Catalytic } \\
\text { Sites }\end{array}$ & References \\
\hline \multirow{4}{*}{$\begin{array}{c}\text { reduced } \\
\text { graphene oxide } \\
\text { single-wall } \\
\text { carbon } \\
\text { nanotubes } \\
\text { carbon } \\
\text { nanotubes } \\
\text { carbon } \\
\text { nanotubes }\end{array}$} & PMS & phenol & $100 \%$ & $45 \min$ & ${ }^{1} \mathrm{O}_{2}$ & $\begin{array}{c}\mathrm{sp}^{2} \text { carbon, } \\
\text { defective edges }\end{array}$ & Duan et al. [53] \\
\hline & PDS & 4-chlorophenol & $100 \%$ & $60 \mathrm{~min}$ & ${ }^{1} \mathrm{O}_{2}$ & $\begin{array}{l}\mathrm{sp}^{2} \text { carbon, } \\
\text { nonradical } \\
\text { electron-transfer }\end{array}$ & Yun et al. [58] \\
\hline & PDS & phenol & $100 \%$ & $30 \mathrm{~min}$ & / & $\begin{array}{c}\text { nonradical } \\
\text { electron-transfer }\end{array}$ & Ren et al. [59] \\
\hline & PDS & $\begin{array}{c}2,4- \\
\text { dichlorophenol }\end{array}$ & $95.9 \%$ & $30 \mathrm{~min}$ & ${ }^{1} \mathrm{O}_{2}, \mathrm{O}_{2} \bullet-$ & $\mathrm{sp}^{2}$ carbon & Cheng et al. [60] \\
\hline $\begin{array}{l}\text { nitrogen-doped } \\
\text { carbon } \\
\text { nanotubes }\end{array}$ & PMS & phenol & $95.6 \%$ & $10 \mathrm{~min}$ & / & $\begin{array}{c}\text { nonradical } \\
\text { electron-transfer }\end{array}$ & Ren et al. [62] \\
\hline $\begin{array}{l}\mathrm{N} \text {-doping } \\
\text { reduced } \\
\text { graphene oxide }\end{array}$ & PMS & $\begin{array}{l}\text { Sulfachloro- } \\
\text { pyridazine }\end{array}$ & $100 \%$ & $9 \mathrm{~min}$ & $\begin{array}{c}\mathrm{SO}_{4} \stackrel{\bullet-}{,}{ }^{1} \mathrm{O}_{2} \\
{ }^{\circ} \mathrm{OH},\end{array}$ & $\begin{array}{l}\text { hydroxyl group, } \\
\mathrm{sp}^{2} \text { carbon, } \\
\text { pyridine } \mathrm{N}, \\
\text { pyrrole } \mathrm{N}, \\
\text { graphite } \mathrm{N}\end{array}$ & Kang et al. [67] \\
\hline $\begin{array}{l}\text { N-S co-doped } \\
\text { graphene }\end{array}$ & PMS & $\begin{array}{c}\text { methyl } \\
p \text {-hydroxy- } \\
\text { benzoate }\end{array}$ & $100 \%$ & $30 \mathrm{~min}$ & $\begin{array}{c}\mathrm{SO}_{4} \stackrel{\bullet-}{,} \cdot{ }^{1} \mathrm{OH}_{2} \\
{ }^{1} \mathrm{O}_{2}\end{array}$ & $\begin{array}{l}\mathrm{sp}^{2} \text { carbon, } \\
\text { pyrrolic N, } \\
\text { pyridinic N, } \\
\text { graphitic N, } \\
\text { thiophenic S }\end{array}$ & Sun et al. [69] \\
\hline $\begin{array}{l}\text { amino- } \\
\text { functionalized } \\
\text { mesoporous } \\
\text { silica anchoring } \\
\mathrm{N} \text {-doped } \\
\text { graphene oxide }\end{array}$ & PMS & bisphenol A & $100 \%$ & $600 \mathrm{~min}$ & ${ }^{1} \mathrm{O}_{2}$ & $\begin{array}{c}\mathrm{sp}^{2} \text { carbon, } \\
\text { phenolic } \\
\text { hydroxyl group, } \\
\text { amino group }\end{array}$ & Zhang et al. [73] \\
\hline $\begin{array}{l}\text { sludge-biochar } \\
\qquad\left(600{ }^{\circ} \mathrm{C}\right)\end{array}$ & PMS & bisphenol & $100 \%$ & $30 \mathrm{~min}$ & ${ }^{1} \mathrm{O}_{2}$ & $\begin{array}{l}\text { ketone structure } \\
\text { inside the } \\
\text { biochar }\end{array}$ & Huang et al. [76] \\
\hline $\begin{array}{l}\text { biochar doped } \\
\text { with } \mathrm{N} \text { and } \mathrm{S}\end{array}$ & PMS & metolachlor & $\begin{array}{c}\text { about } \\
80 \%\end{array}$ & $120 \mathrm{~min}$ & $\cdot \mathrm{OH},{ }^{1} \mathrm{O}_{2}$ & $\begin{array}{c}\text { surface ketone of } \\
\text { biochar }\end{array}$ & Ding et al. [77] \\
\hline
\end{tabular}


Table 2. Cont.

\begin{tabular}{|c|c|c|c|c|c|c|c|}
\hline Catalyst & Oxidant & Target Pollutant & Degrada & $\begin{array}{l}\text { Rate and } \\
\text { e }\end{array}$ & $\begin{array}{c}\text { Radicals } \\
\text { Mechanism }\end{array}$ & $\begin{array}{c}\text { Active Catalytic } \\
\text { Sites }\end{array}$ & References \\
\hline $\begin{array}{l}\text { porous } \\
\text { nitrogen-doped } \\
\text { reduced } \\
\text { graphene oxide }\end{array}$ & PMS & phenol & $100 \%$ & $25 \mathrm{~min}$ & $\begin{array}{c}\bullet \mathrm{OH},{ }^{1} \mathrm{O}_{2} \\
\mathrm{O}_{2}{ }^{\bullet-}\end{array}$ & $\begin{array}{l}\text { structure } \\
\text { vacancies with } \\
\text { two nitrogen } \\
\text { atoms of } \\
\text { graphene } \\
\text { structure }\end{array}$ & Wu et al. [78] \\
\hline $\begin{array}{c}\text { sludge-derived } \\
\text { biochar }\end{array}$ & PDS & sulfamethoxazole & $94.6 \%$ & $180 \mathrm{~min}$ & ${ }^{1} \mathrm{O}_{2}$ & $\begin{array}{c}\mathrm{sp}^{2} \text { carbon, } \\
\mathrm{Fe}(\mathrm{II}), \mathrm{N} \text { atoms }\end{array}$ & Yin et al. [79] \\
\hline $\begin{array}{l}\text { nitrogen-doped } \\
\text { sludge carbon }\end{array}$ & PMS & methylene blue & $98.7 \%$ & $20 \mathrm{~min}$ & $\begin{array}{c}\mathrm{SO}_{4} \stackrel{\bullet-}{\bullet}, \cdot \mathrm{OH}, \\
{ }^{1} \mathrm{O}_{2}\end{array}$ & not mentioned & Hu et al. [81] \\
\hline $\begin{array}{l}\text { graphited } \\
\text { nanodiamond }\end{array}$ & PDS & phenol & $100 \%$ & $10 \mathrm{~min}$ & $\begin{array}{c}\mathrm{SO}_{4} \stackrel{\bullet-}{-} \cdot{ }^{\bullet} \mathrm{OH}, \\
{ }^{1} \mathrm{O}_{2}\end{array}$ & $\begin{array}{c}\text { nonradical } \\
\text { electron-transfer }\end{array}$ & Lee et al. [82] \\
\hline $\begin{array}{l}\text { with a core/shell } \\
\text { structure }\end{array}$ & PMS & phenol & $100 \%$ & $90 \mathrm{~min}$ & / & $\begin{array}{l}\text { of graphite } \\
\text { structure }\end{array}$ & Duan er al. [83] \\
\hline $\begin{array}{l}\text { porous carbon } \\
\text { aerogel }\end{array}$ & PDS & rhodamine B & $100 \%$ & $60 \mathrm{~min}$ & ${ }^{1} \mathrm{O}_{2}, \mathrm{O}_{2} \cdot-$ & $\begin{array}{c}\mathrm{sp}^{2} \text { carbon, } \\
\text { defective edges } \\
\text { and the carbon } \\
\text { edges of carbon } \\
\text { aerogel }\end{array}$ & Jiang et al. [85] \\
\hline $\begin{array}{c}\text { N-doped } \\
\text { chitosan-derived } \\
\text { carbon } \\
\text { nanosheets }\end{array}$ & PMS & sulfacetamide & $100 \%$ & $10 \mathrm{~min}$ & ${ }^{1} \mathrm{O}_{2}, \mathrm{O}_{2} \bullet-$ & $\begin{array}{l}\mathrm{sp}^{2} \text { carbon, } \\
\text { graphitic } \mathrm{N}\end{array}$ & Chen et al. [86] \\
\hline
\end{tabular}

\section{Evolution of ${ }^{1} \mathrm{O}_{2}$ by Activating PDS/PMS with Metal Catalysts and Their Composite}

Transition metals and metal oxides, such as $\mathrm{Co}, \mathrm{Mn}, \mathrm{Fe}, \mathrm{Cu}$, are effective catalysts for activating PDS/PMS, normally without extra assistance of light and heat. The activation processes with transition metals highly rely on the interaction between PDS/PMS and active redox sites, during which ${ }^{\bullet} \mathrm{OH}$ and $\mathrm{SO}_{4}{ }^{\bullet-}$ are typically produced as the primary oxidative species. However, thanks to the improvement of analytical techniques, some recent studies found that ${ }^{1} \mathrm{O}_{2}$ can also be generated from multiple non-radical pathways in metal/PDS or metal/PMS system configurations, including PDS/PMS self-decomposition, recombination of $\mathrm{O}_{2}{ }^{\bullet}$, and the mutual effect between catalysts and PDS/PMS $[87,88]$. Interestingly, these processes could take place either simultaneously or coupled with radical oxidations as illustrated in Tables 3 and 4 , which summarize the ${ }^{1} \mathrm{O}_{2}$ evolution by activating PDS/PMS via heterogeneous transition metals.

\subsection{Iron-Based Catalysts}

Iron-based materials (e.g., zero-valent iron, $\mathrm{Fe}_{3} \mathrm{O}_{4}$ ) are widely used in AOPs because they are cheap and environmental-friendly. In general, the PMS/PDS activation with ironbased materials is accompanied by transformation from $\mathrm{Fe}$ (II) to $\mathrm{Fe}(\mathrm{III})$ and the generation of ${ }^{\bullet} \mathrm{OH}$ and $\mathrm{SO}_{4}{ }^{\bullet-}$ (Equations (17)-(19)) [89]. Therefore, the amount of structural $\mathrm{Fe}(\mathrm{II})$ is a critical factor for catalytic PMS/PDS oxidation of organic pollutants:

$$
\begin{gathered}
\mathrm{Fe}^{2+}+\mathrm{HSO}_{5}{ }^{-} \rightarrow \mathrm{Fe}^{3+}+\mathrm{SO}_{4}{ }^{\bullet-}+\mathrm{OH}^{-} \\
\mathrm{Fe}^{2+}+\mathrm{S}_{2} \mathrm{O}_{8}{ }^{2-} \rightarrow \mathrm{Fe}^{3+}+\mathrm{SO}_{4}{ }^{--}+\mathrm{SO}_{4}{ }^{2-} \\
\mathrm{SO}_{4}{ }^{\bullet-}+\mathrm{H}_{2} \mathrm{O} \rightarrow \mathrm{SO}_{4}{ }^{2-}+{ }^{\bullet} \mathrm{OH}+\mathrm{H}^{+}
\end{gathered}
$$

Yet non-radical oxidation is rarely reported for the $\mathrm{Fe}^{0} / \mathrm{PMS}$ or $\mathrm{Fe}^{0} / \mathrm{PDS}$ systems. The involvement of non-radical process can be observed under some specific conditions. In the study reported by $\mathrm{Li}$ et al., the spike of $\mathrm{Cu}^{2+}$ could enhance efficiency of the $\mathrm{Fe}^{0} / \mathrm{PMS}$ 
system by producing ${ }^{1} \mathrm{O}_{2}, \mathrm{O}_{2}{ }^{\bullet-}$ and also ${ }^{\bullet} \mathrm{OH}$ [90]. Similarly, the corrosion of $\mathrm{Fe}^{0}$ produces $\mathrm{Fe}^{2+}$ to activate PMS to form ${ }^{\bullet} \mathrm{OH}$. However, the process could be interfered by $\mathrm{Cu}^{2+}$ spiking. $\mathrm{Cu}^{2+}$ would transform to $\mathrm{Cu}^{0}, \mathrm{Cu}^{+}$and $\mathrm{Cu}_{2} \mathrm{O}$ by reacting with $\mathrm{Fe}^{0}$. The newly formed surface composite layer mediates PMS decomposition to a new pathway with production of ${ }^{1} \mathrm{O}_{2}$ and $\mathrm{O}_{2}{ }^{\bullet-}$. Yang et al. obtained the same results that ${ }^{1} \mathrm{O}_{2}$ and $\mathrm{O}_{2}{ }^{--}$were dominant species and coexisted with ${ }^{\bullet} \mathrm{OH}$ in the $\mathrm{Fe}^{0}$-montmorillonite/PMS system [91]. Montmorillonite would alter the $\mathrm{Fe}^{0}$ surface oxidation layer which may affect the activation process [92].

Another common iron catalyst is the nanoscale $\mathrm{Fe}_{3} \mathrm{O}_{4}$ which exhibits better stability than zero valent iron. The catalysis ability of $\mathrm{Fe}_{3} \mathrm{O}_{4}$ relies on its surface structural $\mathrm{Fe}(\mathrm{II})$ but not released $\mathrm{Fe}^{2+}$ ions. To overcome magnetic aggregation, $\mathrm{Fe}_{3} \mathrm{O}_{4}$ nanoparticles can be typically immobilized on functional supports to yield a controllable structure. The composite materials activate PMS/PDS with diverse active components so as to form multiple ROSs. Pi et al. obtained $\mathrm{OBC}-\mathrm{Fe}_{3} \mathrm{O}_{4}$ via coating $\mathrm{Fe}_{3} \mathrm{O}_{4}$ nanoparticles onto oxidized biochar $(\mathrm{OBC})$ with better adsorption and pollutant degradation performance than $\mathrm{Fe}_{3} \mathrm{O}_{4}$ and oxidized biochar [93]. A stable chemical bond was established between spherical $\mathrm{Fe}_{3} \mathrm{O}_{4}$ and $\mathrm{OBC}$. The oxygen content of the catalyst increased after reaction, indicating that the oxygen-containing functional group as a bridge for electron transfer played an important role in the process of adsorption and degradation. $\mathrm{Fe}_{3} \mathrm{O}_{4}$ activated $\mathrm{PDS}$ to produce radicals of ${ }^{\bullet} \mathrm{OH}$ and $\mathrm{SO}_{4}{ }^{\bullet-}$ [94], while the $\mathrm{sp}^{2}$-hybrid $\mathrm{C}$ atom with defective structures and ketone groups mediated electron transfer to generate ${ }^{1} \mathrm{O}_{2}$. Thus multiple ROSs including $\mathrm{SO}_{4}{ }^{\bullet-}$, - $\mathrm{OH}$ and ${ }^{1} \mathrm{O}_{2}$ would participate in the degradation of tetracycline. Moreover, $\mathrm{OBC}$ as carrier of $\mathrm{Fe}_{3} \mathrm{O}_{4}$ promoted the adsorption of tetracycline on the catalyst surface, thereby increasing the interaction between ROSs and tetracycline and enhancing its degradation. Liu et al. designed a core-shell iron-carbon nanocomposite catalyst (Fe@CNs as shown in Figure 4a) using sodium alginate as a template to activate PDS and degrade bisphenol A [95]. Under the protection of the carbon shell, the overall iron leaching was less than $3 \mu \mathrm{g} \cdot \mathrm{L}^{-1}$ as the solution $\mathrm{pH}$ was $5 \sim 9$, far lower than the permissible wastewater discharge standard. The carbon component not only offered larger surface area for the uniform distribution of active sites, but also acted as an excellent electron transfer carrier for PDS catalytic oxidation processes, while the incorporation of Fe enhanced redox activity of the catalyst to favor the PDS activation as evidenced by linear sweep voltammetry (LSV) tests (Figure 4b) [96]. In other similar research works using $\mathrm{Fe}_{3} \mathrm{C} / \mathrm{NC}$ [97] and Fe-N/C [98], it was verified that $\mathrm{Fe}-\mathrm{C}$ composite could express great synergy for catalytic PMS activation. For example, Fe-N/C could exhibit 34-fold higher reactivity than N/carbon alone towards bisphenol $\mathrm{F}$ degradation [98]. Based on the radical scavenging and EPR tests, ${ }^{1} \mathrm{O}_{2}$ was identified as the main reactive species and coexisted with $\mathrm{SO}_{4}{ }^{\bullet-}$ and ${ }^{\bullet} \mathrm{OH}$ under the catalysis of $\mathrm{Fe}-\mathrm{C}$ composite. $\mathrm{N}$-doped $\mathrm{C}$ region acted as the active center for electron transfer, and $\mathrm{Fe}$ affected the electronic state of the adjacent $C$ region and increased the charge density for PMS activation, which is in consistent with the process of PDS activation [99].

Overall, the reaction between reductive Fe and PDS/PMS generally underwent radical processes involving $\mathrm{SO}_{4}{ }^{\bullet-}$ and ${ }^{\bullet} \mathrm{OH}$ oxidations. The modification of Fe-based catalysts with carbon or copper materials would form different reactive sites for collaborative PDS/PMS activation. Carbon and $\mathrm{Cu}$ species are able to activate PDS/PMS to form ${ }^{1} \mathrm{O}_{2}$, while $\mathrm{Fe}^{0}$ or $\mathrm{Fe}^{\mathrm{II}}$ would accelerate regeneration of reactive activators. In addition to $\mathrm{Fe} / \mathrm{C}$ and $\mathrm{Fe} / \mathrm{Cu}$ composites, novel Fe-based glasses have attracted increasing research interest for catalytic activation of PDS/PMS. The Fe-based glasses can be easily prepared with unique atomic packing structure and present in the form of ribbons rather than powders. Zero-valent iron inside glasses could provide abundant reactive sites for peroxides activation but with much lower mass loss so as to ensure an excellent reusability [100,101]. Given the superior activity of Fe-based glasses, future efforts to tune their properties to activate PDS/PMS to produce multiple ROSs including ${ }^{1} \mathrm{O}_{2}$ are highly desirable. 

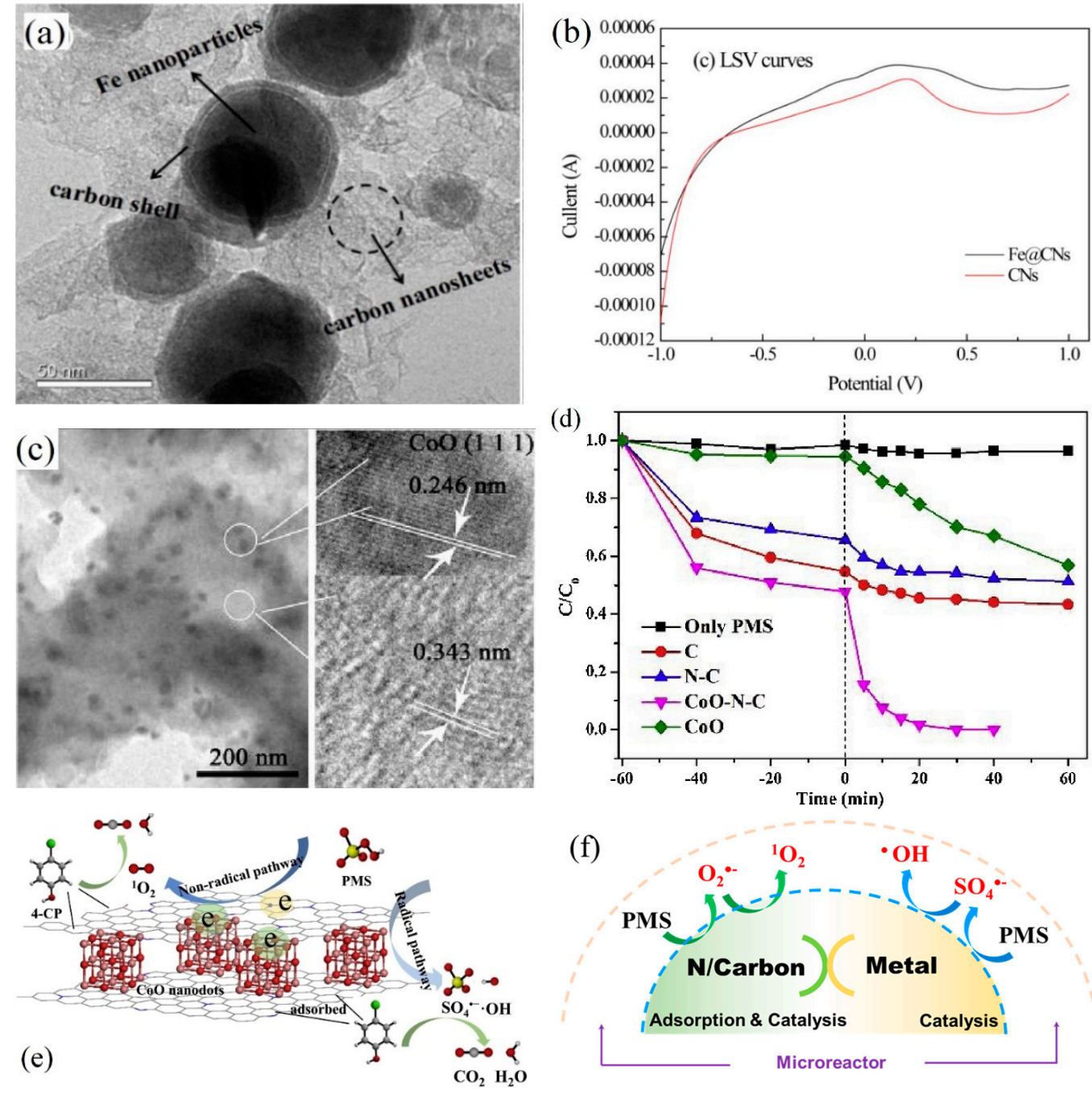

(f)

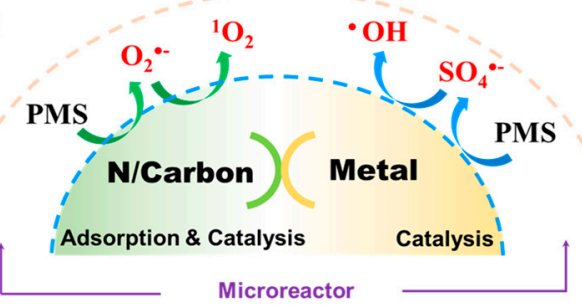

Figure 4. (a) TEM images of core-shell structure and (b) LSV curves of Fe@CNs [94], reprinted with permission from Elsevier; (c) TEM image of $\mathrm{CoO}$ nanodots distribution inside the carbon layers [102], reprinted with permission from Elsevier; (d) performance of CoO-N-C composite in comparison with other catalyst; (e) its catalytic mechanism [102], reprinted with permission; (f) schematic diagram of multi-ROSs generation in PMS/PDS activation systems with carbon/metal composite catalysts.

\subsection{Cobalt-Based Catalysts}

Among transition metal ions $\left(\mathrm{Fe}^{2+}, \mathrm{Co}^{2+}, \mathrm{Mn}^{2+}, \mathrm{Ni}^{2+}\right), \mathrm{Co}^{2+}$ shows the best catalytic performance for PMS activation [103]. However, excessive Co dispersed in water causes more hazardous impacts on both the environment and public health than other metal ions [64]. As an alternative, heterogeneous catalysts, especially cobalt-containing materials, such as $\mathrm{CoOOH}$ [104], and $\mathrm{CoFe}_{2} \mathrm{O}_{4^{-}}$[105], show excellent performance in activating PMS for the generation of ${ }^{1} \mathrm{O}_{2}$. Zhang et al. focused on $\mathrm{Co}-\mathrm{OOH}$ nanoparticles owing to the good hydrophilic and electronic transmission rate [104]. They observed that 2,4DCP could be completely degraded in the $\mathrm{CoOOH} / \mathrm{PMS}$ system within $120 \mathrm{~min}$, whereas the degradation rates for 2,4-DCP in $\mathrm{Co}_{3} \mathrm{O}_{4} / \mathrm{PMS}$ and $\mathrm{CoFe}_{2} \mathrm{O}_{4} / \mathrm{PMS}$ system were $33 \%$ and $73 \%$, respectively. In the Co-catalyzed systems, the redox cycle of $\mathrm{Co}(\mathrm{III}) / \mathrm{Co}(\mathrm{II})$, as evidenced by XPS analysis, was the driving force for PDS/PMS activation as elucidated in Equations (20) and (21). Meanwhile, this redox cycling could be enhanced in the presence of the sufficient surface hydroxyl groups on $\mathrm{CoOOH}$, which expedited the regeneration of $\mathrm{CoOH}^{+}$intermediate to promote catalytic oxidation rate. In addition to sulfate radicals, ${ }^{1} \mathrm{O}_{2}$ was produced via self-decomposition of PMS in the $\mathrm{CoOOH} / \mathrm{PMS}$ system at a rate 
constant of $0.2 \mathrm{M}^{-1} \bullet \mathrm{s}^{-1}$ as shown in Equation (22) (P4 in Figure 5). The main cause of the ${ }^{1} \mathrm{O}_{2}$ formation was attributed to the recombination of $\mathrm{O}_{2} \cdot{ }^{\bullet-}$ (Equation (23)).

$$
\begin{gathered}
\equiv \mathrm{Co}(\mathrm{III})+\mathrm{HSO}_{5}{ }^{-} \rightarrow \equiv \mathrm{Co}(\mathrm{II})+\mathrm{SO}_{5}{ }^{\bullet-}+\mathrm{H}^{+} \\
\equiv \mathrm{Co}(\mathrm{II})+\mathrm{HSO}_{5}{ }^{-} \rightarrow \equiv \mathrm{Co}(\mathrm{III})+\mathrm{SO}_{4}{ }^{\bullet-}+\mathrm{OH}^{-} \\
\mathrm{HSO}_{5}{ }^{-}+\mathrm{SO}_{5}{ }^{2-} \rightarrow \mathrm{HSO}_{4}{ }^{-}+\mathrm{SO}_{4}{ }^{2-}+{ }^{1} \mathrm{O}_{2} \\
2 \mathrm{O}_{2}{ }^{\bullet-}+2 \mathrm{H}_{2} \mathrm{O} \rightarrow{ }^{1} \mathrm{O}_{2}+\mathrm{H}_{2} \mathrm{O}_{2}+2 \mathrm{OH}^{-}
\end{gathered}
$$

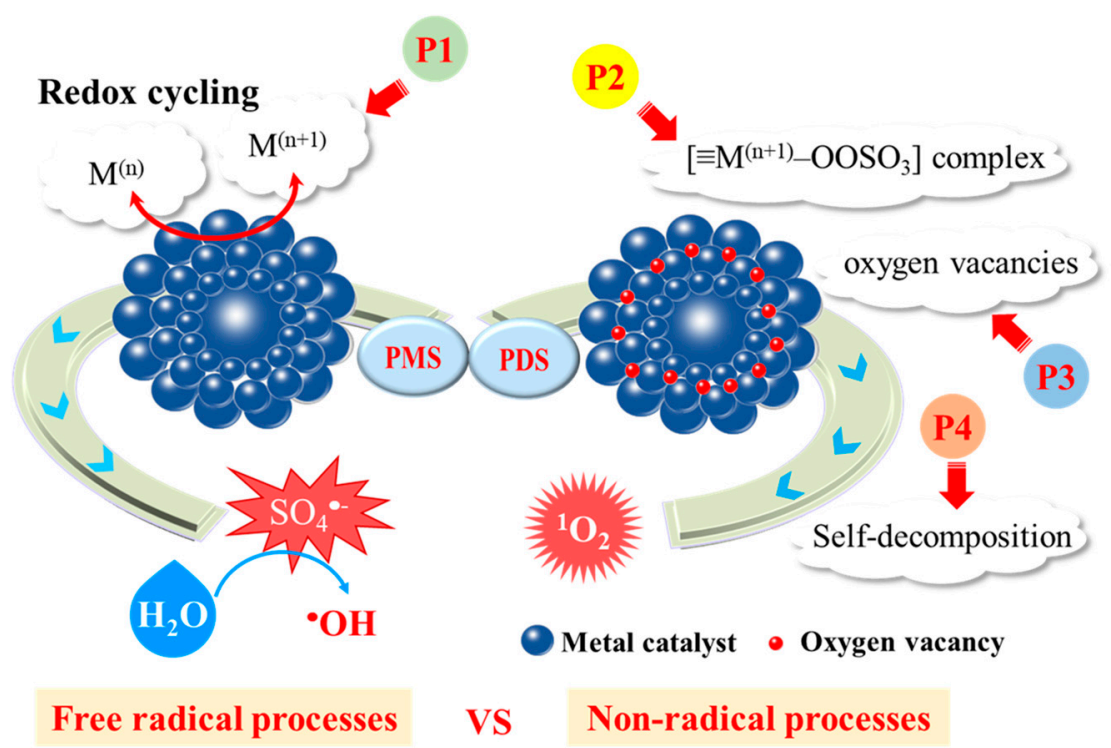

Figure 5. Schematic illustration of pathways of PMS/PDS activation in metal-catalyzed heterogeneous systems. P1: redox cycling; P2: formation of metal-PMS/PDS complex; P3: generation of oxygen vacancies; P4: PMS/PDS self-decomposition.

For the systems containing both radical and non-radical processes, some water matrices may function as the influential factor that regulates the contribution for ${ }^{1} \mathrm{O}_{2}$. In a PMS activation system with $\mathrm{Co}_{3} \mathrm{O}_{4}$ nanowires as the catalyst, the effect of carbonate ions $\left(\mathrm{CO}_{3}{ }^{2-}\right)$ was investigated for bisphenol A degradation [106]. It was revealed that ${ }^{\bullet} \mathrm{OH}$ and $\mathrm{SO}_{4}{ }^{\bullet-}$ were the main ROSs in the absence of $\mathrm{CO}_{3}{ }^{2-}\left(\mathrm{P} 1\right.$ in Figure 5), but in the presence of $\mathrm{CO}_{3}{ }^{2-}$, a faster contaminant degradation rate was obtained because of the enhanced formation of ${ }^{1} \mathrm{O}_{2}$, especially when the solution $\mathrm{pH}$ rose up to the $\mathrm{pH}_{\mathrm{PZC}}$ of $\mathrm{Co}_{3} \mathrm{O}_{4}$. Carbonate anions could suppress Co dissolution and facilitate the conversion of catalytic center from $\mathrm{Co}$ (II) to $\mathrm{Co}(\mathrm{III})$, while the system switched from radical oxidation to ${ }^{1} \mathrm{O}_{2}$-dominated non-radical process. These findings endorsed that the coupling of $\mathrm{Co}(\mathrm{III})$ and $\mathrm{CO}_{3}{ }^{2-} / \mathrm{OH}^{-}$would have a synergistic effect by functioning as electron and proton acceptors, instead of a simple $\mathrm{Co}(\mathrm{II}) / \mathrm{Co}$ (III) redox cycling. The metal particles tend to aggregate in the water phase, and $\mathrm{Co}^{2+}$ ions would leach once the $\mathrm{pH}$ value is not well controlled. To overcome these limitations, nano-carbon materials, including two- or three-dimensional carbon materials, are commonly employed for metal-carbon nanocomposites fabrication. Co immobilized with carbon can offer higher catalytic efficiency for PMS or PDS activation. The co-doping strategy can not only adjust the electronic structure of the carbon catalyst, but also prevent metal leaching and simplify catalyst recovery. The immobilization of Co on carbon materials, as shown in Figure 4c, would also reduce secondary contamination of Co leaching [107]. The Co-C interaction could increase the Fermi level and chemical activity of functionalized C atoms to enhance PMS or PDS activation for pollutants degradation (Figure 4d). Several points were proposed for the reaction mechanism. First, the involvement of adsorptive carbon can facilitate the enrichment of aqueous pollutants and PMS ions to the microenvironment of internal active sites [108]. Second, the reactive Co species effectively 
activate PMS or PDS with production of $\mathrm{SO}_{4}{ }^{\bullet-}$ and ${ }^{\bullet} \mathrm{OH}$ to achieve free radical oxidation. Third, the $\mathrm{Co}$ and $\mathrm{N}$ doping produced more defect sites and carbon graphitization, which could promote electron transfer and activate adjacent $\mathrm{C}$ atoms for ${ }^{1} \mathrm{O}_{2}$ based non-radical degradation (Figure 4e). Moreover, the $\mathrm{Co} / \mathrm{Fe}$ co-doping into plain $\mathrm{N}-\mathrm{C}$ was expected to form synergistic effect for more efficient catalysis $[109,110]$. The existence of binary metals would accelerate redox cycling like a Fenton-like reaction. The simultaneous generation of multi-ROSs in both carbon-mediated and metal-mediated PMS/PDS activation systems facilitated deeper degradation of target pollutants (Figure 4f).

\subsection{Manganese-Based Catalysts}

Mn-associated catalysts are effective PMS/PDS activators with advantageous features like Mn being an Earth-abundant element and less toxic in nature, as compared to Co [111]. For example, a series of manganese nano catalysts with different oxidative states demonstrated potential catalysis for atrazine elimination through radical and non-radical activation of PMS [112]. $\alpha-\mathrm{MnO}_{2}$ nanowires revealed higher catalytic performance due to their ability to facilitate electron transfer to maintain the redox cycle between $\mathrm{Mn}$ (IV) and $\mathrm{Mn}(\mathrm{III})$. In another study, both $\alpha-\mathrm{MnO}_{2}$ and $\beta-\mathrm{MnO}_{2}$ (one-dimensional) displayed relatively effective PDS activation for selective mineralization of organic pollutants in wastewater [19]. Huang et al. found that ${ }^{1} \mathrm{O}_{2}$ could be formed in the $\mathrm{PMS} / \mathrm{MnO}_{2}$ system under acidic conditions [113]. A metastable manganese intermediate $\left(\equiv \mathrm{MnIV}-\mathrm{O}-\mathrm{O}-\mathrm{SO}_{3}\right)$ formed when $\mathrm{S}_{2} \mathrm{O}_{8}{ }^{2-}$ attached on the $\mathrm{MnO}_{2}$ surface. $\equiv \mathrm{MnIV}-\mathrm{O}-\mathrm{O}-\mathrm{SO}_{3}$ would further react with $\mathrm{S}_{2} \mathrm{O}_{8}{ }^{2-}$ to break the $\mathrm{Mn}(\mathrm{IV})-\mathrm{O}$ bond along with the formation of $\mathrm{O}_{2}{ }^{\bullet-}$. Afterward, ${ }^{1} \mathrm{O}_{2}$ was generated as the primary ROSs through direct oxidation of $\mathrm{O}_{2}{ }^{\bullet-}$ by $\mathrm{Mn}(\mathrm{IV})$, $\mathrm{O}_{2}{ }^{\bullet-}$ recombination, and the reaction between $\mathrm{O}_{2}{ }^{\bullet-}$ and metastable manganese intermediates at neutral pH (Equations (24)-(26)). Besides, Mn-doped graphite-based carbon nitride $(\mathrm{MnCN})$ also provided good catalysis for PMS oxidation of acetaminophen (ACT) [114]. As indicated in the XPS spectrum, $40 \%$ of Mn existed in the Mn(III) state, while $\mathrm{N}$ coordinated with $\mathrm{Mn}$ as Mn-N. Under optimized conditions, 100\% of ACT was removed within 15 min in the MnCN/PMS system. PMS would attach to Mn-N and produce superoxide anions which later transformed to ${ }^{1} \mathrm{O}_{2}$. Compared to phenols and nitrobenzene, ACT exhibited significant degradation by ${ }^{1} \mathrm{O}_{2}$ via attacking electron-donating acylamino groups:

$$
\begin{gathered}
2[\equiv \mathrm{Mn}(\mathrm{IV})-\mathrm{OH}]^{\mathrm{III}}+\mathrm{HS}_{2} \mathrm{O}_{8}{ }^{-} \rightarrow 2\left[\equiv \mathrm{Mn}(\mathrm{IV})-\mathrm{O}-\mathrm{O}-\mathrm{SO}_{3}\right]^{\mathrm{II}}+3 \mathrm{H}^{+} \\
2\left[\equiv \mathrm{Mn}(\mathrm{IV})-\mathrm{O}-\mathrm{O}-\mathrm{SO}_{3}\right]^{\mathrm{II}}+4 \mathrm{H}_{2} \mathrm{O}+\mathrm{S}_{2} \mathrm{O}_{8}{ }^{2-} \rightarrow 2[\equiv \mathrm{Mn}(\mathrm{III})-\mathrm{OH}]^{\mathrm{II}}+4 \mathrm{SO}_{4}{ }^{2-}+2 \mathrm{O}_{2}{ }^{-}+8 \mathrm{H}^{+} \\
{\left[\equiv \mathrm{Mn}(\mathrm{IV})-\mathrm{O}-\mathrm{O}-\mathrm{SO}_{3}\right]^{\mathrm{II}}+\mathrm{O}_{2}{ }^{\bullet-}+\mathrm{OH}^{-} \rightarrow[\equiv \mathrm{Mn}(\mathrm{III})-\mathrm{OH}]^{\mathrm{II}}+\mathrm{SO}_{4}{ }^{2-}+{ }^{1} \mathrm{O}_{2}}
\end{gathered}
$$

Oxygen vacancies could be important active site for Mn oxides (P3 in Figure 5). For instance, Jie et al. manufactured the $\mathrm{MnO}_{2-\mathrm{x}}$ rattle-type microspheres that a large number of oxygen-defective $\mathrm{MnO}_{2}$ nanoflakes vertically arranged on the surface (OD$\left.\mathrm{MnO}_{2-\mathrm{x}}-\mathrm{RM}\right)$, and altered the amount of oxygen vacancies by $\mathrm{H}_{2}$ reduction treatment for various treatment times (20, 40, 60 and $80 \mathrm{~min})$ [115]. PMS was activated to form ${ }^{1} \mathrm{O}_{2}$ due to the presence of oxygen vacancies and unique nanoarchitecture of the $\mathrm{MnO}_{2-\mathrm{x}}$ rattle-type microspheres catalyst. The turnover frequency of the optimized catalyst sample OD- $\mathrm{MnO}_{2-\mathrm{x}}-\mathrm{RM}(40 \mathrm{~min})$ revealed it as the best-performing catalyst even though OD$\mathrm{MnO}_{2-\mathrm{x}}-\mathrm{RM}(60 \mathrm{~min})$ possessed the richest oxygen vacancies.

\subsection{Copper-Based Catalysts}

Copper oxide $(\mathrm{CuO})$ is considered as one of the most promising catalysts for the activation of PDS and PMS when evaluated in term of cost and availability. The activity and stability of nanocrystals is strongly dependent on orientation, dimension as well as the crystallographic structure. Du et al. found that sheet-like $\mathrm{CuO}$ with preferential exposed crystal facet (001) exhibited much higher reactivity toward catalytic PDS activation than spindle-like $\mathrm{CuO}$ [88]. The activation of PDS on $\mathrm{CuO}$ mainly followed a non-radical process [116]. To control the morphology and structure of $\mathrm{CuO}$ catalyst, Wang et al. applied 
polyethylene glycol as a structure directing agent [117]. They noticed that $\mathrm{CuO}-3$ with controlled structure reflected better catalytic potential for PMS activation and relatively higher degradation of phenolic compounds and associated organic pollutants found in water. The complex intermediate $\equiv \mathrm{Cu}(\mathrm{II})-(\mathrm{O}) \mathrm{OSO}_{3}{ }^{-}$on catalyst surface was proposed to react with PMS to produce $\mathrm{O}_{2}{ }^{\bullet-}$. It was verified that ${ }^{1} \mathrm{O}_{2}$ rather than ${ }^{\bullet} \mathrm{OH}$ and $\mathrm{SO}_{4}{ }^{\bullet-}$ was the main ROSs, and $\mathrm{O}_{2}{ }^{\bullet-}$ could be an important precursor of ${ }^{1} \mathrm{O}_{2}$ in the PMS/CuO-3 system. Interestingly, some reports also found that the $\mathrm{CuO} / \mathrm{PMS}$ system could perform efficient for saline wastewater treatment due to the good anti-interference nature $[118,119]$.

Another strategy refers to the use of functional support to obtain hybrid structure as well as relocate site electrons. It was reported that the $\mathrm{Cu}-\mathrm{O}-\mathrm{C}$ bond formed by immobilizing $\mathrm{CuO}$ on two-dimensional rGO greatly promoted catalytic PDS oxidation for trichlorophenol [88]. The confinement of rGO in hybrid material improved interfacial electron mobility between catalyst and PMS [120]. Also the Cu-O-rGO composite showed better potential to produce more oxygen vacancies for ${ }^{1} \mathrm{O}_{2}$ generation. Artificial creation of oxygen vacancies effectively modulates the electronic structure of metal oxides, including $\mathrm{CuO}$. This kind of modulation has been proven efficient for boosting catalytic performance [121]. Yu et al. verified that the incorporation of copper into zinc ferrite catalyst could harvest rich oxygen vacancies. The co-participation of $\mathrm{Fe}$ and $\mathrm{Cu}$ moieties contribute more active sites for catalytic PMS decomposition, and ${ }^{1} \mathrm{O}_{2}$ and $\mathrm{O}_{2}{ }^{\bullet-}$ were detected as the dominant ROSs. According to their results, $96.6 \%$ of ciprofloxacin (CIP) was mineralized within $15 \mathrm{~min}$, and the catalyst exhibited good stability and reusability [122]. Furthermore, an easy hydrothermal-calcination route was applied to synthesize $\mathrm{CuO}-\mathrm{CeO}_{2}$ composite for the activation of PMS to generate ${ }^{1} \mathrm{O}_{2}$ [123]. The rate constant noted for the $\mathrm{CuO}-\mathrm{CeO}_{2} / \mathrm{PMS}$ system was 7-11 times higher than that observed in other systems, such as PMS alone, or $\mathrm{CeO}_{2}$ /PMS, and $\mathrm{CuO} / \mathrm{PMS}$ systems. Better electron transfer and more oxygen vacancies reflected the synergy between $\mathrm{CuO}$ and $\mathrm{CeO}_{2}$, which contributed to remarkable ${ }^{1} \mathrm{O}_{2}$ generation during PMS decomposition.

The surface structure of catalysts could be an influential factor. Jawad et al. reported that the incorporation of non-redox $\mathrm{MgO}$ into $\mathrm{CuO} / \mathrm{Fe}_{3} \mathrm{O}_{4}$ catalyst would surprisingly enhance the catalytic performance on PMS activation, and also switch the activation mechanism from a free-radical pathway with generation of $\mathrm{SO}_{4} \cdot{ }^{\bullet-}$ to ${ }^{1} \mathrm{O}_{2}$-based non-radical process [124]. The $\mathrm{Cu}(\mathrm{II}) / \mathrm{Cu}(\mathrm{III})$ redox pair no longer acted as the catalytic center, but the incorporation of $\mathrm{MgO}$ facilitated the formation of deficient copper $[\equiv \mathrm{Cu}(\mathrm{III})-\mathrm{OH}]^{\mathrm{II}}$ and the enrichment of extensive ionic PMS. Then $[\equiv \mathrm{Cu}(\mathrm{III})-\mathrm{OH}]^{\mathrm{II}}$ reacted with PMS to form $\left[\equiv \mathrm{Cu}(\mathrm{III})-\mathrm{OOSO}_{3}\right]$ complex (Equation (27), P2 in Figure 5). In other cases, divalent copper complex in form of $\left[\equiv \mathrm{Cu}(\mathrm{II})-\mathrm{OOSO}_{3}\right]$ acted as this vital intermediate [120]. The electron transfer from $\mathrm{SO}_{5}{ }^{2-}$ to $\equiv \mathrm{Cu}$ sites ultimately demonstrated the decomposition of $\left[\equiv \mathrm{Cu}-\mathrm{OOSO}_{3}\right]$ to form $\mathrm{O}_{2}{ }^{\bullet-}$ as a precursor of ${ }^{1} \mathrm{O}_{2}$ (Equation (28)):

$$
\begin{array}{r}
{[\equiv \mathrm{Cu}(\mathrm{III})-\mathrm{OH}]^{\mathrm{II}}+\mathrm{HSO}_{5}{ }^{-} \rightarrow\left[\equiv \mathrm{Cu}(\mathrm{III})-(\mathrm{O}) \mathrm{OSO}_{3}{ }^{-}\right]^{\mathrm{I}}+\mathrm{H} 2 \mathrm{O}} \\
2\left[\equiv \mathrm{Cu}(\mathrm{III})-(\mathrm{O}) \mathrm{OSO}_{3}\right]^{\mathrm{I}}+\mathrm{HSO}_{5}{ }^{-}+3 \mathrm{H}_{2} \mathrm{O} \rightarrow 2[\equiv \mathrm{Cu}(\mathrm{II})-\mathrm{OH}]^{\mathrm{I}}+2 \mathrm{O}_{2}{ }^{\bullet-}+3 \mathrm{SO}_{4}{ }^{2-}+7 \mathrm{H}^{+}
\end{array}
$$

\subsection{Other Metallic Catalysts}

Addtionally, metal oxides of perovskites $\left(\mathrm{ABO}_{3}\right.$ structure) [8] and spinel $\left(\mathrm{AB}_{2} \mathrm{O}_{4}\right.$ structure) [125] have attracted increasing interest due to their high stability and strong oxidation potential. At octahedral and tetrahedral sites, different types of cations with similar values of crystal field stabilization energies can substitute the metal situating in crystal lattice and form partial oxygen defects for the regulation of the band structure and the recycle of redox pairs [126]. The oxygen vacancies on the surface of metal/metal oxide play an important role in the generation of ${ }^{1} \mathrm{O}_{2}$ and efficient activation of PMS. The surface and lattice oxygen vacancies are expected to facilitate oxygen adsorption and storage, and accelerate oxygen mobility, which are important for rapid generation of $\mathrm{O}_{2}{ }^{\bullet-}$ and their following conversion to ${ }^{1} \mathrm{O}_{2}[105,127]$. Gao et al. prepared $\mathrm{LaBO}_{3}$ perovskites with different $\mathrm{B}$ site metal $(\mathrm{B}=\mathrm{Fe}, \mathrm{Zn}, \mathrm{Mn}$ and $\mathrm{Ni})$ to investigate the effect of $\mathrm{B}$ site metals on 
the PMS activation and ${ }^{1} \mathrm{O}_{2}$ generation route [8]. It was observed that as high as $21.8 \%$ of oxygen defects was monitored for $\mathrm{LaNiO}_{3}$. Ofloxacin (OFX) was completely degraded by the $\mathrm{LaNiO}_{3} / \mathrm{PMS}$ system, which could be assigned to the effect of oxygen defects on ${ }^{1} \mathrm{O}_{2}$ generation. The surface oxygen defects of perovskite could lower the energy barrier of spontaneous PMS decomposition on $\mathrm{LaBO}_{3}$ surface, which is an important pathway for the formation of ${ }^{1} \mathrm{O}_{2}$. Chen et al. also suggested that the cobalt ions in the tetrahedral sites were inclined to be substituted by manganese ions with larger ionic radius [128] accompanied by the generation of vacancies on the $\mathrm{O}$ sites [125]. Meanwhile, some active oxygen might react with $\mathrm{HSO}_{5}{ }^{-}$to produce ${ }^{1} \mathrm{O}_{2}$. More oxygen vacancies would facilitate interfacial electron transfer of PMS activation [129,130].

Table 3. Performance and mechanism of typical heterogeneous metallic catalysts for PDS/PMS oxidation of pollutants.

\begin{tabular}{|c|c|c|c|c|c|c|c|}
\hline Oxidant & Catalyst & Target/Pollutant & Degradatio & Rate and & $\begin{array}{l}\text { Radicals } \\
\text { Involve }\end{array}$ & $\begin{array}{l}\text { Active Catalytic SitesOr } \\
\text { Activation Mechanism }\end{array}$ & References \\
\hline \multirow{4}{*}{ PDS } & $\beta-\mathrm{MnO}_{2}$ & phenol & over $99 \%$ & $180 \mathrm{~min}$ & ${ }^{1} \mathrm{O}_{2}, \mathrm{O}_{2}{ }^{\bullet-}$ & $\begin{array}{l}\text { metastable manganese } \\
\text { intermediates for } \mathrm{O}_{2}^{\bullet-} \\
\text { generation }\end{array}$ & $\begin{array}{l}\text { Zhu et al. } \\
\text { [19] }\end{array}$ \\
\hline & sheet-like $\mathrm{CuO}$ & $\begin{array}{c}2,4,6- \\
\text { trichlorophenol }\end{array}$ & $90 \%$ & $180 \mathrm{~min}$ & $\begin{array}{c}\bullet \mathrm{OH}, \\
\text { non-radical }\end{array}$ & $\begin{array}{c}\text { facet (001) of } \mathrm{CuO}, \\
\text { electron-defective center }\end{array}$ & Du et al. [88] \\
\hline & $\mathrm{CoFe}_{2} \mathrm{O}_{4-\mathrm{x}}$ & bisphenol A & $98 \%$ & $60 \min$ & 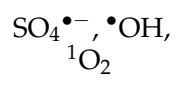 & $\begin{array}{c}\mathrm{Fe}(\mathrm{III}) / \mathrm{Fe}(\mathrm{II}), \\
\mathrm{Co}(\mathrm{III}) / \mathrm{Co}(\mathrm{II}), \text { oxygen } \\
\text { vacancies, }\end{array}$ & $\begin{array}{l}\text { Wu et al. } \\
\text { [105] }\end{array}$ \\
\hline & $\mathrm{CuO}$ & ciprofloxacin & $100 \%$ & $30 \mathrm{~min}$ & $\begin{array}{l}{ }^{1} \mathrm{O}_{2}, \mathrm{O}_{2}^{\bullet-} \\
\mathrm{SO}_{4}^{\bullet-} \cdot{ }^{\prime} \mathrm{OH}\end{array}$ & $\begin{array}{c}\mathrm{Cu}(\mathrm{II}) / \mathrm{Cu}(\mathrm{III}) \text { for } \mathrm{O}_{2}{ }^{\bullet-} \\
\text { and }{ }^{1} \mathrm{O}_{2}, \mathrm{Cu}(\mathrm{I}) / \mathrm{Cu}(\mathrm{II}) \text { for } \\
\mathrm{SO}_{4}{ }^{\bullet-}, \bullet \mathrm{OH}\end{array}$ & $\begin{array}{l}\text { Xing et al. } \\
\text { [116] }\end{array}$ \\
\hline \multirow{16}{*}{ PMS } & $\mathrm{LaNiO}_{3}$ & ofloxacin & $93 \%$ & $10 \mathrm{~min}$ & $\begin{array}{c}{ }^{1} \mathrm{O}_{2}, \mathrm{SO}_{4}^{\bullet-}, \\
\mathrm{OH}^{\bullet}\end{array}$ & $\begin{array}{l}\mathrm{Ni}(\mathrm{III}) / \mathrm{Ni}(\mathrm{II}), \text { oxygen } \\
\text { vacancies }\end{array}$ & Gao et al. [8] \\
\hline & $\mathrm{nZVI} / \mathrm{Cu}^{2+}$ & rhodamine B & $99.3 \%$ & $60 \min$ & $\begin{array}{l}{ }^{1} \mathrm{O}_{2}, \mathrm{O}_{2} \bullet- \\
\mathrm{SO}_{4} \cdot-, \cdot{ }^{\prime}\end{array}$ & $\begin{array}{l}\mathrm{Fe}(\mathrm{III}) / \mathrm{Fe}(\mathrm{II}) \\
\mathrm{Cu}(\mathrm{II}) / \mathrm{Cu}(\mathrm{I})\end{array}$ & Li et al. [90] \\
\hline & $\mathrm{Fe}^{0}-\mathrm{Mt}$ & bisphenol A & $\begin{array}{c}99.3 \% \text { at } \mathrm{pH} \\
3\end{array}$ & $120 \mathrm{~min}$ & $\begin{array}{l}{ }_{1}^{1} \mathrm{O}_{2}, \mathrm{O}_{2} \bullet- \\
\mathrm{SO}_{4}^{\bullet} \cdot-, \cdot{ }^{\prime} \cdot \mathrm{H}^{\prime}\end{array}$ & $\mathrm{Fe}^{0}$, released $\mathrm{Fe}^{2+}$ & $\begin{array}{l}\text { Yang et al. } \\
\text { [91] }\end{array}$ \\
\hline & $\mathrm{CoOOH}$ & $\begin{array}{c}2,4- \\
\text { dichlorophenol }\end{array}$ & $100 \%$ & $120 \mathrm{~min}$ & ${ }_{\mathrm{SO}_{4}^{1} \mathrm{O}_{2}, \mathrm{O}_{2} \bullet-}^{\bullet} \mathrm{OH}$ & $\mathrm{Co}(\mathrm{III}) / \mathrm{Co}(\mathrm{II}),-\mathrm{OH}$ & $\begin{array}{l}\text { Zhang et al. } \\
\text { [104] }\end{array}$ \\
\hline & $\mathrm{Co}_{3} \mathrm{O}_{4} / \mathrm{CO}_{3}^{2-}$ & bisphenol A & $100 \%$ & $10 \mathrm{~min}$ & $\begin{array}{l}{ }^{1} \mathrm{O}_{2}, \mathrm{O}_{2} \cdot- \\
\mathrm{SO}_{4} \cdot-{ }^{\prime}\end{array}$ & $\begin{array}{c}\mathrm{Co}(\mathrm{III}) / \mathrm{Co}(\mathrm{II}), \mathrm{OH}^{-}, \\
\mathrm{CO}_{3}{ }^{2-}\end{array}$ & $\begin{array}{l}\text { Zhu et al. } \\
\text { [106] }\end{array}$ \\
\hline & $\begin{array}{l}\text { Mn oxides in } \\
\text { different } \\
\text { structure }\end{array}$ & atrazine & $100 \%$ & $100 \mathrm{~min}$ & ${ }^{1} \mathrm{O}_{2}, \mathrm{SO}^{\bullet-}{ }^{\bullet-}$ & $\begin{array}{c}\mathrm{Mn}(\mathrm{IV}) / \mathrm{Mn}(\mathrm{III}) \\
\mathrm{Mn}(\mathrm{III}) / \mathrm{Mn}(\mathrm{II})\end{array}$ & $\begin{array}{l}\text { Zeng et al. } \\
\text { [112] }\end{array}$ \\
\hline & $\delta-\mathrm{MnO}_{2}$ & bisphenol A & $42 \%$ & $10 \mathrm{~min}$ & 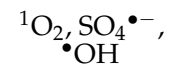 & $\begin{array}{c}\delta-\mathrm{MnO}_{2} \text { direct oxidation, } \\
\mathrm{Mn}(\mathrm{IV}) / \mathrm{Mn}(\mathrm{III})\end{array}$ & $\begin{array}{c}\text { Huang et al. } \\
{[113]}\end{array}$ \\
\hline & $\mathrm{Mn}-\mathrm{g}-\mathrm{C}_{3} \mathrm{~N}_{4}$ & acetaminophen & $100 \%$ & $15 \mathrm{~min}$ & ${ }^{1} \mathrm{O}_{2}, \mathrm{O}_{2}^{\bullet-}$ & $\begin{array}{c}\mathrm{Mn}(\mathrm{III}) / \mathrm{Mn}(\mathrm{III}) \text { in the } \\
\text { N-pot }\end{array}$ & $\begin{array}{l}\text { Fan et al. } \\
\text { [114] }\end{array}$ \\
\hline & $\begin{array}{l}\text { Oxygen- } \\
\text { defective } \\
\mathrm{MnO}_{2}\end{array}$ & bisphenol A & $100 \%$ & $60 \mathrm{~min}$ & ${ }^{1} \mathrm{O}_{2}, \mathrm{SO}_{4}^{\bullet-}$ & oxygen vacancies & $\begin{array}{l}\text { Yu et al. } \\
\text { [115] }\end{array}$ \\
\hline & $\mathrm{CuO}$ & bisphenol A & $100 \%$ & $60 \mathrm{~min}$ & ${ }^{1} \mathrm{O}_{2}, \mathrm{O}_{2} \cdot-$ & $\begin{array}{c}\mathrm{Cu}(\mathrm{II})-(\mathrm{O})-\mathrm{OSO}_{3}^{-} \\
\text {formed on surface of } \\
\mathrm{CuO} \text { for } \mathrm{O}_{2}{ }^{\bullet-} \text { generation }\end{array}$ & $\begin{array}{l}\text { Wang et al. } \\
\text { [117] }\end{array}$ \\
\hline & $\begin{array}{l}\text { magnetic } \mathrm{CuO} \\
\text { nanosheet }\end{array}$ & $\begin{array}{l}\text { AO7 in high } \\
\text { salinity } \\
\text { wastewater }\end{array}$ & $95.8 \%$ & $30 \mathrm{~min}$ & ${ }^{1} \mathrm{O}_{2}, \mathrm{SO}_{4}^{\bullet-}$ & $\begin{array}{c}\text { synergistic effect of } \\
\mathrm{Cu}(\mathrm{I}) / \mathrm{Cu}(\mathrm{II}) \text { and } \\
\mathrm{Fe}(\mathrm{II}) / \mathrm{Fe}(\mathrm{III})\end{array}$ & Li et al. [118] \\
\hline & $\begin{array}{c}\text { copper } \\
\text { substituted } \\
\text { zinc ferrate }\end{array}$ & ciprofloxacin & $96.6 \%$ & $15 \mathrm{~min}$ & $\begin{array}{l}{ }^{1} \mathrm{O}_{2}, \mathrm{O}_{2}^{\bullet-} \\
\mathrm{SO}_{4}^{\bullet-}, \cdot \bullet \mathrm{H}^{\prime}\end{array}$ & $\begin{array}{c}\mathrm{Fe}(\mathrm{III}) / \mathrm{Fe}(\mathrm{II}), \mathrm{Cu}(\mathrm{II}) / \\
\mathrm{Cu}(\mathrm{I}), \text { oxygen vacancies }\end{array}$ & $\begin{array}{l}\text { Yu et al. } \\
\text { [122] }\end{array}$ \\
\hline & $\mathrm{CuO}-\mathrm{CeO}_{2}$ & rhodamine B & $100 \%$ & $60 \mathrm{~min}$ & $\begin{array}{l}{ }^{1} \mathrm{O}_{2}, \mathrm{O}_{2} \cdot- \\
\mathrm{SO}_{4}^{\bullet},{ }^{\bullet} \mathrm{OH}\end{array}$ & $\begin{array}{c}\mathrm{Ce}(\mathrm{IV}) / \mathrm{Ce}(\mathrm{III}) \\
\mathrm{Cu}(\mathrm{II}) / \mathrm{Cu}(\mathrm{I}), \text { oxygen } \\
\text { vacancies, electron } \\
\text { transfer }\end{array}$ & Li et al. [123] \\
\hline & $\mathrm{CuOMgO} / \mathrm{Fe}_{3} \mathrm{O}_{4}$ & 4-chlorophenol & $100 \%$ & $40 \mathrm{~min}$ & ${ }^{1} \mathrm{O}_{2}, \mathrm{O}_{2} \cdot-$ & $\begin{array}{c}{\left[\equiv \mathrm{Cu}^{(\mathrm{III})}-\mathrm{OOSO}_{3}\right]} \\
\text { intermediates for } \mathrm{O}_{2} \bullet- \\
\text { generation }\end{array}$ & $\begin{array}{c}\text { Jawad et al. } \\
{[124]}\end{array}$ \\
\hline & $\mathrm{Co}_{2} \mathrm{Mn}_{1} \mathrm{O}_{4}$ & triclosan phenol & $96.4 \%$ & $30 \mathrm{~min}$ & ${ }^{1} \mathrm{O}_{2}, \mathrm{SO}_{4}^{\bullet-}$ & $\begin{array}{c}\text { oxygen vacancies, } \\
\text { Co(II) } / \mathrm{Co}(\mathrm{III}) \\
\mathrm{Mn}(\mathrm{III}) / \mathrm{Mn}(\mathrm{II}) / \mathrm{Mn}(\mathrm{IV})\end{array}$ & $\begin{array}{c}\text { Chen et al. } \\
\text { [125] }\end{array}$ \\
\hline & $\mathrm{LaCo}_{0.4} \mathrm{Cu}_{0.6} \mathrm{O}_{3}$ & phenol & $100 \%$ & $12 \mathrm{~min}$ & $\begin{array}{l}{ }^{1} \mathrm{O}_{2}, \mathrm{SO}_{4}^{\bullet-}, \\
\quad \cdot \mathrm{OH}\end{array}$ & $\begin{array}{c}\mathrm{Co}(\mathrm{II}) / \mathrm{Co}(\mathrm{III}) \\
\mathrm{Cu}(\mathrm{II}) / \mathrm{Cu}(\mathrm{I}), \text { oxygen } \\
\text { vacancies }\end{array}$ & $\begin{array}{c}\text { Lu et al. } \\
\text { [130] }\end{array}$ \\
\hline
\end{tabular}

In addition to the usual transition metals, noble metals also show potential capability to activate PMS with generation of ${ }^{1} \mathrm{O}_{2}$ for the degradation of selective organic pollutants. $\mathrm{Ahn}$ et al. found that noble metals including $\mathrm{Pt}, \mathrm{Pd}, \mathrm{Au}$, and $\mathrm{Ag}$ immobilized on $\mathrm{Al}_{2} \mathrm{O}_{3}$ 
or $\mathrm{TiO}_{2}$ could mediate electron transfer from organics to PMS to achieve non- radical oxidation [131]. The catalytic performance exhibited a dependency on the type of noble metal in an order of $\mathrm{Pd}>\mathrm{Pt} \approx \mathrm{Au} \gg \mathrm{Ag}$. To further understand the intrinsic catalytic mechanism, Wang et al. anchored Pd particles in the cavity of $\mathrm{g}-\mathrm{C}_{3} \mathrm{~N}_{4}$ as a heterogeneous catalyst $\left(\mathrm{Pd} / \mathrm{g}-\mathrm{C}_{3} \mathrm{~N}_{4}\right)$ to activate PMS with generation of ${ }^{1} \mathrm{O}_{2}$ and $\mathrm{O}_{2}{ }^{\bullet-}$ for bisphenol A degradation [132]. Noteworthily, less than $10 \%$ of bisphenol A could be removed by g- $\mathrm{C}_{3} \mathrm{~N}_{4} / \mathrm{PMS}$ alone, while $91 \%$ of bisphenol A could be degraded in $60 \mathrm{~min}$ by $\mathrm{Pd} / \mathrm{g}$ $\mathrm{C}_{3} \mathrm{~N}_{4} / \mathrm{PMS}$. However, it was observed that $\mathrm{Pd}^{0}$ might convert to $\mathrm{Pd}^{(\mathrm{II})}$ as indicated by the XPS results that the $\mathrm{Pd}^{0} / \mathrm{Pd}^{\mathrm{II}}$ ratio would decrease from 2.02 to 1.19 after the reaction (Equations (29)-(34)). The catalytic ability was significantly influenced by solution $\mathrm{pH}$ and reached maximum at $\mathrm{pH} 9$ because ${ }^{1} \mathrm{O}_{2}$ would attack deprotonated organic compounds at a higher oxidation rate compared to undissociated ones. The mechanism involves the following points: (i) $\mathrm{H}_{2} \mathrm{O}_{2}$ and $\mathrm{Pd}^{0} \cdot \mathrm{OH}$ formed by the reaction between $\mathrm{HSO}_{5}{ }^{-}$and $\mathrm{H}_{2} \mathrm{O}$ under catalysis of $\mathrm{Pd}^{0}$ (Equations (29)-(30)); (ii) the disassociation of $\mathrm{Pd}^{0} \cdot \mathrm{OH}$ generates ${ }^{1} \mathrm{O}_{2}$ according to Equations (31) and (32); (iii) PMS was catalyzed by $\mathrm{Pd}^{0}$ into intermediate - $\mathrm{OHPd}^{0} \mathrm{SO}_{4}{ }^{-}$(Equation (33)), which was then decomposed into $\mathrm{Pd}^{\mathrm{II}}, \mathrm{SO}_{4}{ }^{2-}$ and $\mathrm{H}^{+}$ (Equation (34)):

$$
\begin{gathered}
\mathrm{HSO}_{5}{ }^{-}+\mathrm{H}_{2} \mathrm{O} \rightarrow \mathrm{H}_{2} \mathrm{O}_{2}+\mathrm{HSO}_{4}{ }^{-} \\
2 \mathrm{Pd}^{0}+\mathrm{H}_{2} \mathrm{O}_{2} \rightarrow 2 \mathrm{Pd}^{0} \cdot \mathrm{OH} \\
2 \mathrm{Pd}^{0} \cdot \mathrm{OH} \rightarrow \mathrm{H}_{2} \mathrm{O}+\mathrm{Pd}^{0} \cdot \mathrm{O}+\mathrm{Pd}^{0} \\
2 \mathrm{Pd}^{0} \cdot \mathrm{O} \rightarrow 2 \mathrm{Pd}^{0}+{ }^{1} \mathrm{O}_{2} \\
\mathrm{HSO}_{5}{ }^{-}+\mathrm{Pd}^{0} \rightarrow \mathrm{OHPd}^{0} \mathrm{SO}_{4}{ }^{\bullet-} \\
\cdot \mathrm{OHPd}^{0} \mathrm{SO}_{4}{ }^{--}+\mathrm{H}_{2} \mathrm{O} \rightarrow \cdots \rightarrow \mathrm{Pd}^{\mathrm{II}}+\mathrm{SO}_{4}{ }^{2-}+2 \mathrm{H}^{+}
\end{gathered}
$$

\begin{tabular}{|c|c|c|c|c|c|c|c|}
\hline Oxidant & Catalyst & Target/Pollutant & Degrada & $\begin{array}{l}\text { Rate and } \\
\text { e }\end{array}$ & $\begin{array}{l}\text { Radicals } \\
\text { Involve }\end{array}$ & $\begin{array}{c}\text { Active Catalytic } \\
\text { SitesOr Activation } \\
\text { Mechanism }\end{array}$ & References \\
\hline \multirow[t]{2}{*}{ PDS } & $\begin{array}{l}\text { oxidation } \\
\text { biochar } \\
\text { supported } \\
\text { magnetite } \\
\text { particles }\end{array}$ & tetracycline & $92.3 \%$ & $120 \mathrm{~min}$ & 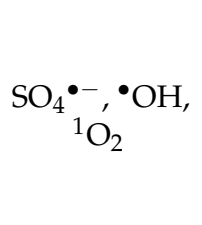 & $\begin{array}{c}\mathrm{Fe}(\mathrm{II}) / \mathrm{Fe}(\mathrm{III}), \\
\text { sp2-hybrid C atom } \\
\text { with defective } \\
\text { structures, ketone } \\
\text { groups mediated } \\
\text { electron transfer }\end{array}$ & Pi et al. [93] \\
\hline & $\begin{array}{l}\text { Nuclear-shell } \\
\text { structure } \\
\text { iron-carbon }\end{array}$ & bisphenol A & $96 \%$ & $30 \mathrm{~min}$ & $\begin{array}{l}\mathrm{SO}_{4} \bullet-, \cdot \bullet \mathrm{OH}, \\
{ }^{1} \mathrm{O}_{2}, \mathrm{O}_{2}^{\bullet--}\end{array}$ & $\begin{array}{l}\mathrm{Fe}^{0} \mathrm{Fe}(\mathrm{II}) / \mathrm{Fe}(\mathrm{III}), \\
\text { electron transfer for } \\
\mathrm{O}_{2}{ }^{\bullet-} \text { formation to } \\
\text { produce }{ }^{1} \mathrm{O}_{2}\end{array}$ & $\begin{array}{l}\text { Liu et al. } \\
\text { [95] }\end{array}$ \\
\hline \multirow{3}{*}{ PMS } & $\begin{array}{l}\text { sludge-derived } \\
\text { magnetic } \\
\mathrm{Fe}^{0} / \mathrm{Fe}_{3} \mathrm{C}\end{array}$ & ciprofloxacin & $99 \%$ & $20 \mathrm{~min}$ & $\begin{array}{c}\mathrm{SO}_{4} \bullet-, \cdot \bullet \mathrm{OH}, \\
{ }^{1} \mathrm{O}_{2}, \mathrm{O}_{2} \cdot-\end{array}$ & $\begin{array}{c}\mathrm{Fe}^{0}, \mathrm{Fe}(\mathrm{II}) / \mathrm{Fe}(\mathrm{III}), \\
\text { electron transfer for } \\
\mathrm{O}_{2}^{\bullet-} \text { formation to } \\
\text { produce }{ }^{1} \mathrm{O}_{2}\end{array}$ & $\begin{array}{c}\text { Zhu et al. } \\
\text { [96] }\end{array}$ \\
\hline & $\begin{array}{c}\mathrm{Fe}_{3} \mathrm{C} \\
\text { embedded on } \\
\text { carbon }\end{array}$ & ibuprofen & $100 \%$ & $30 \mathrm{~min}$ & $\begin{array}{c}\mathrm{SO}_{4}{ }^{\bullet-}{ }^{1} \mathrm{O}_{2} \\
{ }^{\bullet} \mathrm{OH}\end{array}$ & $\begin{array}{l}\mathrm{Fe}(\mathrm{II}) / \mathrm{Fe}(\mathrm{III}), \\
\text { N-doped carbon area, } \\
\text { enhanced electron } \\
\text { transfer process due to } \\
\text { the carbon shell }\end{array}$ & $\begin{array}{c}\text { Zhang et al. } \\
\text { [97] }\end{array}$ \\
\hline & $\begin{array}{l}\text { iron and } \\
\text { nitrogen } \\
\text { co-doped } \\
\text { porous carbon }\end{array}$ & bisphenol F & $97.1 \%$ & $90 \mathrm{~min}$ & $\begin{array}{c}\mathrm{SO}_{4}{ }^{\bullet-},{ }^{\bullet} \mathrm{OH}, \\
{ }^{1} \mathrm{O}_{2}, \mathrm{O}_{2} \bullet-\end{array}$ & $\begin{array}{l}\text { pyridine } \mathrm{N} \text {, graphite } \\
\mathrm{N} \text {, adjacent } \mathrm{C} \text { region of } \\
\text { Fe-doping }\end{array}$ & $\begin{array}{l}\text { Wu et al. } \\
\text { [98] }\end{array}$ \\
\hline
\end{tabular}

Table 4. Performance and mechanism of metal-carbon nanocomposite catalysts for PDS/PMS oxidation of pollutants. 
Table 4. Cont.

\begin{tabular}{|c|c|c|c|c|c|c|c|}
\hline Oxidant & Catalyst & Target/Pollutant & \multicolumn{2}{|c|}{$\begin{array}{c}\text { Degradation Rate and } \\
\text { Time }\end{array}$} & $\begin{array}{l}\text { Radicals } \\
\text { Involve }\end{array}$ & \multirow{2}{*}{$\begin{array}{c}\text { Active Catalytic } \\
\text { SitesOr Activation } \\
\text { Mechanism }\end{array}$} & References \\
\hline & $\begin{array}{l}\text { N-doped } \\
\text { porous carbon } \\
\text { embedded } \\
\text { with CoO } \\
\text { nanodots }\end{array}$ & chlorophenol & $100 \%$ & $30 \mathrm{~min}$ & $\begin{array}{c}\mathrm{SO}_{4}{ }^{\bullet-},{ }^{1} \mathrm{O}_{2} \\
{ }^{\circ} \mathrm{OH},\end{array}$ & & $\begin{array}{l}\text { Xie et al. } \\
\text { [102] }\end{array}$ \\
\hline & $\begin{array}{l}\text { core-shell } \\
\text { Co@C } \\
\text { nanoparticles } \\
\text { with nitrogen } \\
\text { and sulfur }\end{array}$ & $\begin{array}{c}p \text { - } \\
\text { hydroxybenzoic } \\
\text { acid }\end{array}$ & $100 \%$ & $45 \mathrm{~min}$ & ${ }_{2}^{\bullet} \mathrm{OH}$ & $\begin{array}{l}\mathrm{sp}^{2} \text { carbon, defect sites } \\
\text { procuced by Co and } \mathrm{N} \\
\text { doping, } \mathrm{Co}(\mathrm{II}) / \mathrm{Co}(\mathrm{III})\end{array}$ & $\begin{array}{l}\text { Tian et al. } \\
\text { [107] }\end{array}$ \\
\hline & $\begin{array}{l}\text { CoFe alloy } \\
\text { nanoparticles } \\
\text { encapsulated } \\
\text { in nitrogen } \\
\text { doped } \\
\text { graphitic } \\
\text { carbon }\end{array}$ & norfloxacin & $94.4 \%$ & $20 \mathrm{~min}$ & $\mathrm{O}_{2}^{\bullet} \mathrm{OH}$ & $\begin{array}{c}\mathrm{Co}(\mathrm{II}) / \mathrm{Co}(\mathrm{III}), \\
\mathrm{Fe}(\mathrm{II}) / \mathrm{Fe}(\mathrm{III}), \\
\text { neighboring } \mathrm{C} \text { atoms } \\
\text { of graphitic N, } \\
\text { self-decomposition of } \\
\text { PMS }\end{array}$ & $\begin{array}{l}\text { Ding et al. } \\
\text { [109] }\end{array}$ \\
\hline & $\begin{array}{l}\text { carbon-based } \\
\text { Fe-Co oxide } \\
\text { derived from } \\
\text { Prussian blue }\end{array}$ & $\begin{array}{c}4- \\
\text { aminobenzoic } \\
\text { acid ethyl ester }\end{array}$ & $95.5 \%$ & $60 \mathrm{~min}$ & $\begin{array}{c}\mathrm{SO}_{4} \stackrel{\bullet-}{{ }^{1} \mathrm{O}_{2}}{ }^{\bullet} \mathrm{OH}, \\
\end{array}$ & $\begin{array}{c}\mathrm{Co}(\mathrm{II}) / \mathrm{Co}(\mathrm{III}), \\
\mathrm{Fe}(\mathrm{II}) / \mathrm{Fe}(\mathrm{III}), \mathrm{sp}^{2} \\
\text { hybridized carbon, } \\
\text { pyridinic-N and } \\
\text { pyrrolic-N }\end{array}$ & $\begin{array}{l}\text { Liu et al. } \\
\text { [110] }\end{array}$ \\
\hline & $\begin{array}{c}\mathrm{Pd} \\
\text { nanoparticles } \\
\text { anchored } \mathrm{C}_{3} \mathrm{~N}_{4}\end{array}$ & bisphenol A & $91 \%$ & $60 \mathrm{~min}$ & $\begin{array}{c}\mathrm{SO}_{4} \stackrel{\bullet-}{{ }^{1} \mathrm{O}_{2}} \cdot{ }^{\bullet} \mathrm{OH}, \\
\end{array}$ & $\begin{array}{c}\mathrm{Pd}^{0} / \mathrm{Pd}(\mathrm{II}), \text { electron } \\
\text { transfer for }{ }^{1} \mathrm{O}_{2} \\
\text { production }\end{array}$ & $\begin{array}{c}\text { Wang et al. } \\
\text { [132] }\end{array}$ \\
\hline
\end{tabular}

\section{Implications for In Situ Applications and Future Perspectives}

\subsection{Implications for In Situ Applications}

The wide occurrence of emerging organic contaminants, such as personal care products and pharmaceuticals (PCPPs), endocrine disrupting chemicals (EDCs), pesticides and surfactants, in natural environment has forced rapid development of PDS/PMS-based AOPs for in situ environmental remediation. Efficiency of conventional PDS/PMS oxidation processes is usually affected by practical matrix conditions, such as temperature, solution $\mathrm{pH}$ and salinity. Typically, it is generally recognized that high salinity is a big roadblock for the degradation of organic contaminants in AOPs. Radicals of ${ }^{\bullet} \mathrm{OH}$ and $\mathrm{SO}_{4}{ }^{\bullet-}$ can easily reacted with $\mathrm{Cl}^{-}, \mathrm{NO}_{3}{ }^{-}$to form corresponding byproducts of $\mathrm{Cl}^{\bullet}$ and $\mathrm{NO}_{3}{ }^{\bullet}$, and even suppressed in the existence of carbonate and phosphate. This inhibition under high salinity seems to be greatly weakened during non-radical AOPs [118]. An efficient destruction of bisphenol A in high salinity water was observed during ${ }^{1} \mathrm{O}_{2}$-dominated PMS activation by using nitrogen-doped carbon as the catalyst [133]. Anions including $\mathrm{Cl}^{-}, \mathrm{NO}_{3}{ }^{-}, \mathrm{HCO}_{3}{ }^{-}, \mathrm{H}_{2} \mathrm{PO}_{4}{ }^{-}$even in concentrations up to $500 \mathrm{mM}$ exhibited insignificant effects on bisphenol A degradation. This insensitivity to the water matrix is related to the unstable nature of PMS. The unsymmetrical PMS easily undergo self-decomposition under nucleophilic attack by high dose of $\mathrm{Cl}^{-}, \mathrm{HCO}_{3}{ }^{-}$, and $\mathrm{H}_{2} \mathrm{PO}_{4}{ }^{-}$with production of ${ }^{1} \mathrm{O}_{2}$. Unlike $\mathrm{SO}_{4}{ }^{\bullet-}$ and ${ }^{\bullet} \mathrm{OH},{ }^{1} \mathrm{O}_{2}$ is a moderate oxidant that unable to oxidize these anions to anion-derived radicals. Besides, soil nature organic matter (NOM) is a complex factor for PMS/PDS activation. $\mathrm{SO}_{4}{ }^{\bullet-}$ and ${ }^{\bullet} \mathrm{OH}$ radicals are likely to oxidize these background organic constituents so that displaying suppression for target pollutants degradation, but NOM with abundant quinone or semiquinone groups is also a potent PMS activator in alkaline conditions as indicated in Section 3. Moreover, NOM in aquatic systems commonly acts as photosensitizer for ${ }^{1} \mathrm{O}_{2}$ formation rather than quencher [26], so the negative effect of NOM in ${ }^{1} \mathrm{O}_{2}$-dominated system might be marginally limited $[19,91]$. A bench column 
study by Yang et al. showed that $\mathrm{HCO}_{3}{ }^{-}$and $\mathrm{Cl}^{-}$did not show detrimental effects on TCE degradation and the effect of NOM were negligible at high PMS dosage during in situ chemical oxidation of trichloroethylene (TCE) with bimetallic Fe-Mn oxide as the catalyst [134]. Their EPR and radical scavenging results implied that $\mathrm{SO}_{4}{ }^{\bullet-}, \bullet \mathrm{OH}$ and ${ }^{1} \mathrm{O}_{2}$ contributed to TCE degradation. Involvement of various highly ROSs during AOPs resulted in high rate of TCE degradation and dichlorination compared to conventional $\mathrm{H}_{2} \mathrm{O}_{2}$-based in situ oxidation. Besides, solution $\mathrm{pH}$ is another influential parameter depending on characteristics of activator. In homogeneous activation systems, ${ }^{1} \mathrm{O}_{2}$ could be directly generated via PDS/PMS activation under neutral $(6.5 \pm 0.3)$ and alkaline condition because the surface hydroxyl groups could improve the chemical binding with PDS/PMS. In heterogeneous system, metal could activate PMS with formation of ${ }^{1} \mathrm{O}_{2}$ in a broader $\mathrm{pH}$ range [91]. The nature of catalyst structure, singlet oxygenation and electron transfer are crucial factors behind the formation of ${ }^{1} \mathrm{O}_{2}$ [90].

In addition, the impact of subsurface minerals on PDS/PMS-based in situ oxidation cannot be ignored. Studies by Zhu et al. indicated that PDS interacting with different crystalline $\mathrm{MnO}_{2}$ forms would transform to ${ }^{1} \mathrm{O}_{2}$ as the reactive species for phenol abatement. Ahmad et al. and Yu et al. found that synthetic birnessite (manganese oxide) and goethite (iron oxide) were effective mineral for both PDS and PMS activation during in situ chemical oxidation $[135,136]$. Non-radical pathways accounted for oxidation in birnessite and goethite catalytic PMS systems, and this process could be promoted in presence of soil organic matter. It was concluded that the PDS/PMS decomposition mostly relied on the nature of the mineral surface as well as the rate of metal dissolution. Once persulfate was injected into the contaminated plume, its decomposition occurred due to frequent interaction with aquifer materials including soil organic matter and minerals. Sra et al. verified that the injection of unactivated persulfate into a gasoline source zone could abate a maximum of $46 \%-86 \%$ of gasoline contaminants after two months of remediation [137].

\subsection{Future Perspectives}

Despite the fact PDS/PMS-based AOPs with production of ${ }^{1} \mathrm{O}_{2}$ have shown interesting properties in bench scale studies, there are several issues deserve further scientific investigations.

First, except for $\mathrm{NaN}_{3}, \mathrm{FFA}$, more suitable quenchers and quantitative methods are needed to further prove key role of singlet oxygen in the rapid degradation of pollutants.

Second, although MFCMs were recognized as desirable potential catalysts, discrepant catalytic activity has been obtained due to different material configuration and surface functional groups. Further studies have to be carried out to figure out the effect of MFCMs characteristics on the reaction efficiency and its key relationship with ROSs production.

Third, the adoption of PDS/PMS-based AOPs for full scale applications largely relies on high pollutant degradation efficacy and cost-effective catalysts. Thus, a novel cheap and stable catalyst which can activate PDS/PMS to exploit multiple oxidation pathways would be truly desirable. In general, ${ }^{1} \mathrm{O}_{2}$ is recognized to be more selective to mildly oxidize electron-rich substrates and shows much stronger anti-interference capability towards inorganic ions as well as natural organic matters. Therefore, ${ }^{1} \mathrm{O}_{2}$ can be properly used for disinfection of pathogenic bacteria. By contrast, $\mathrm{SO}_{4}{ }^{\bullet-}$ and ${ }^{\bullet} \mathrm{OH}$ exhibit more powerful oxidation ability but poor resistance to background water impurities because of radical quenching. Therefore, degradation via multiple oxidation pathways involving different ROSs, such as $\mathrm{SO}_{4}{ }^{\bullet-}, \mathrm{O}_{2}{ }^{\bullet-}, \cdot \mathrm{OH}$ and ${ }^{1} \mathrm{O}_{2}$ in the same reaction system, is expected to reach a higher oxidation efficiency, especially for wastewaters containing antibiotics and antibiotic resistant bacteria. Finally, the novel techniques available for PDS activation are still limited as compared to PMS-based AOPs. It is well-known that the commercial PDS is cheaper than PMS, and efficient PDS-based AOPs are expected to produce less sulfate ion than PMS-based AOPs after reactions since PMS only constitutes $1 / 3$ of Oxone ${ }^{\circledR}$. It is thus crucial to develop more PDS-based catalysts with efficient generation of different ROSs for the sake of future commercialization. 


\section{Conclusions}

This paper presents an overview of ${ }^{1} \mathrm{O}_{2}$ formation via non-radical activation of PDS/PMS in both homogenous and heterogeneous reaction systems. In homogeneous systems, ketones, quinones and alkaline are effective to activate PMS to generate ${ }^{1} \mathrm{O}_{2}$ while PDS is more likely to be decomposed with generation of radicals. For heterogeneous systems, MFCMs including CNTs, reduced GO and biochar materials have received much attentions. N-doping and structure tailoring endow MFCMs with more lattice vacancies and defect sites for the exploitation of PDS/PMS. In addition, ketone functional groups are able to provide additionally accessible active sites for MFCMs, and the catalytic efficiency could be significantly tuned by controlling the number of ketone groups. Furthermore, the effectiveness of transition metals such as $\mathrm{Co}, \mathrm{Cu}$ and $\mathrm{Mn}$ were discussed in regard of activating PDS or PMS to initiate ${ }^{1} \mathrm{O}_{2}$ production under some specific conditions. Surface complexation and redox reactions were proposed as the main mechanisms for metal-mediated activation. Additionally, composite catalysts with multiple functions were discussed. Metal would be doped or immobilized into carbon and membrane to show synergistic effect with less metal leaching, enhanced catalytic stability and reusability. Overall, ${ }^{1} \mathrm{O}_{2}$ can be formed either as the main ROSs to dominate the oxidative degradation or co-exist with radicals including $\mathrm{SO}_{4}{ }^{\bullet-}, \mathrm{O}_{2}{ }^{\bullet-}$ and ${ }^{\bullet} \mathrm{OH}$. It is largely evidenced that catalysts, oxidant type, reaction parameters are all influential factors for ${ }^{1} \mathrm{O}_{2}$ production.

Author Contributions: G.X.: Wrote the manuscript. T.X.: Wrote and revised the manuscript. M.F.: Wrote the part of non-metal carbon activation. Y.X.: Wrote the part of homogeneous activation. T.Z.: Wrote the part of manganese and copper oxide activation. H.T.M.: Prepare part of in situ application; J.B.: Manuscript structure guidance. J.D.: Writing, review, and editing. All authors have read and agreed to the published version of the manuscript.

Funding: The research is supported by Natural Science Foundation of China (41907153), the special fund from the Hubei Provincial Engineering Research Center of Systematic Water Pollution Control (20190729), Natural Science Foundation of Hubei Province (2018CFB262) and Fundamental Research Funds for the Central Universities of the China University of Geosciences (Wuhan) (CUG170646).

Institutional Review Board Statement: Not applicable.

Informed Consent Statement: Not applicable.

Acknowledgments: We thank Samuel Raphael Ackah for the effort of language editing.

Conflicts of Interest: There are no conflicts of interest to declare.

\section{References}

1. Liang, C.; Su, H.-W. Identification of Sulfate and Hydroxyl Radicals in Thermally Activated Persulfate. Ind. Eng. Chem. Res. 2009, 48, 5558-5562. [CrossRef]

2. Tsitonaki, A.; Petri, B.; Crimi, M.; MosbÆK, H.; Siegrist, R.L.; Bjerg, P.L. In Situ Chemical Oxidation of Contaminated Soil and Groundwater Using Persulfate: A Review. Crit. Rev. Environ. Sci. Technol. 2010, 40, 55-91. [CrossRef]

3. Wang, J.; Wang, S. Activation of persulfate (PS) and peroxymonosulfate (PMS) and application for the degradation of emerging contaminants. Chem. Eng. J. 2018, 334, 1502-1517. [CrossRef]

4. Oh, W.-D.; Dong, Z.; Lim, T.-T. Generation of sulfate radical through heterogeneous catalysis for organic contaminants removal: Current development, challenges and prospects. Appl. Catal. B Environ. 2016, 194, 169-201. [CrossRef]

5. Du, J.; Bao, J.; Liu, Y.; Kim, S.H.; Dionysiou, D.D. Facile preparation of porous Mn/Fe3O4 cubes as peroxymonosulfate activating catalyst for effective bisphenol A degradation. Chem. Eng. J. 2019, 376, 119193. [CrossRef]

6. Duan, X.; Sun, H.; Shao, Z.; Wang, S. Nonradical reactions in environmental remediation processes: Uncertainty and challenges. Appl. Catal. B Environ. 2018, 224, 973-982. [CrossRef]

7. Bokare, A.D.; Choi, W. Singlet-Oxygen Generation in Alkaline Periodate Solution. Environ. Sci. Technol. 2015, 49, 14392-14400. [CrossRef] [PubMed]

8. Gao, P.; Tian, X.; Nie, Y.; Yang, C.; Zhou, Z.; Wang, Y. Promoted peroxymonosulfate activation into singlet oxygen over perovskite for ofloxacin degradation by controlling the oxygen defect concentration. Chem. Eng. J. 2019, 359, 828-839. [CrossRef]

9. Liu, S.; Zhao, C.; Wang, Z.; Ding, H.; Deng, H.; Yang, G.; Li, J.; Zheng, H. Urea-assisted one-step fabrication of a novel nitrogendoped carbon fiber aerogel from cotton as metal-free catalyst in peroxymonosulfate activation for efficient degradation of carbamazepine. Chem. Eng. J. 2020, 386, 124015. [CrossRef] 
10. DeRosa, M.C.; Crutchley, R.J. Photosensitized singlet oxygen and its applications. Coord. Chem. Rev. 2002, 233, 351-371.

11. Peters, J.W.; Bekowies, P.J.; Winer, A.M.; Pitts, J.N. Potassium perchromate as a source of singlet oxygen. J. Am. Chem. Soc. 1975, 97, 3299-3306. [CrossRef]

12. Stephenson, L.M.; McClure, D.E. Mechanisms in phosphite ozonide decomposition to phosphate esters and singlet oxygen. J. Am. Chem. Soc. 1973, 95, 3074-3076. [CrossRef]

13. Foote, C.S.; Wexler, S.; Ando, W.; Higgins, R. Chemistry of singlet oxygen. IV. Oxygenations with hypochlorite-hydrogen peroxide. J. Am. Chem. Soc. 1968, 90, 975-981. [CrossRef]

14. Du, J.; Xiao, G.; Xi, Y.; Zhu, X.; Su, F.; Kim, S.H. Periodate activation with manganese oxides for sulfanilamide degradation. Water Res. 2020, 169, 115278. [CrossRef]

15. Yu, K.; Yang, S.; Boyd, S.A.; Chen, H.; Sun, C. Efficient degradation of organic dyes by BiAgxOy. J. Hazard. Mater. 2011, 197, 88-96. [CrossRef]

16. Yu, J.; Feng, H.; Tang, L.; Pang, Y.; Zeng, G.; Lu, Y.; Dong, H.; Wang, J.; Liu, Y.; Feng, C.; et al. Metal-free carbon materials for persulfate-based advanced oxidation process: Microstructure, property and tailoring. Prog. Mater. Sci. 2020, 111, 100654. [CrossRef]

17. Ike, I.A.; Linden, K.G.; Orbell, J.D.; Duke, M. Critical review of the science and sustainability of persulphate advanced oxidation processes. Chem. Eng. J. 2018, 338, 651-669. [CrossRef]

18. Wang, Y.; Indrawirawan, S.; Duan, X.; Sun, H.; Ang, H.M.; Tadé, M.O.; Wang, S. New insights into heterogeneous generation and evolution processes of sulfate radicals for phenol degradation over one-dimensional $\alpha-\mathrm{MnO} 2$ nanostructures. Chem. Eng. J. 2015 266, 12-20. [CrossRef]

19. Zhu, S.; Li, X.; Kang, J.; Duan, X.; Wang, S. Persulfate activation on crystallographic manganese oxides: Mechanism of singlet oxygen evolution for nonradical selective degradation of aqueous contaminants. Environ. Sci. Technol. 2019, 53, 307-315. [CrossRef] [PubMed]

20. Xiao, S.; Cheng, M.; Zhong, H.; Liu, Z.; Liu, Y.; Yang, X.; Liang, Q. Iron-mediated activation of persulfate and peroxymonosulfate in both homogeneous and heterogeneous ways: A review. Chem. Eng. J. 2020, 384, 123265. [CrossRef]

21. Zhao, Q.; Mao, Q.; Zhou, Y.; Wei, J.; Liu, X.; Yang, J.; Luo, L.; Zhang, J.; Chen, H.; Chen, H.; et al. Metal-free carbon materialscatalyzed sulfate radical-based advanced oxidation processes: A review on heterogeneous catalysts and applications. Chemosphere 2017, 189, 224-238. [CrossRef] [PubMed]

22. Schweitzer, C.; Schmidt, R. Physical Mechanisms of Generation and Deactivation of Singlet Oxygen. Chem. Rev. 2003, 103, 1685-1757. [CrossRef] [PubMed]

23. Min, D.B.; Boff, J.M. Chemistry and Reaction of Singlet Oxygen in Foods. Compr. Rev. Food Sci. Food Saf. 2002, 1, 58-72. [CrossRef] [PubMed]

24. Neta, P.; Huie, R.E.; Ross, A.B. Rate Constants for Reactions of Inorganic Radicals in Aqueous Solution. J. Phys. Chem. Ref. Data 1988, 17, 1027-1284. [CrossRef]

25. Asghar, A.; Abdul Raman, A.A.; Wan Daud, W.M.A. Advanced oxidation processes for in-situ production of hydrogen peroxide/hydroxyl radical for textile wastewater treatment: A review. J. Clean. Prod. 2015, 87, 826-838. [CrossRef]

26. Mostafa, S.; Rosario-Ortiz, F.L. Singlet Oxygen Formation from Wastewater Organic Matter. Environ. Sci. Technol. 2013, 47, 8179-8186. [CrossRef]

27. Chen, X.; Oh, W.-D.; Lim, T.-T. Graphene-and CNTs-based carbocatalysts in persulfates activation: Material design and catalytic mechanisms. Chem. Eng. J. 2018, 354, 941-976. [CrossRef]

28. Krieger-Liszkay, A. Singlet oxygen production in photosynthesis. J. Exp. Bot. 2005, 56, 337-346. [CrossRef]

29. García-Fresnadillo, D. Singlet Oxygen Photosensitizing Materials for Point-of-Use Water Disinfection with Solar Reactors. ChemPhotoChem 2018, 2, 512-534. [CrossRef]

30. Pibiri, I.; Buscemi, S.; Piccionello, A.P.; Pace, A. Photochemically produced singlet oxygen. ChemPhotoChem 2018, 2, 535-547. [CrossRef]

31. Chen, L.; Yamane, S.; Mizukado, J.; Suzuki, Y.; Kutsuna, S.; Uchimaru, T.; Suda, H. ESR study of singlet oxygen generation and its behavior during the photo-oxidation of P3HT in solution. Chem. Phys. Lett. 2015, 624, 87-92. [CrossRef]

32. Rkanofsky, J. Assay for Singlet-Oxygen Generation by Peroxidases Using 1270-nm Chemiluminescence, InSinglet Oxygen, UV-A, and Ozone; Academic Press: San Diego, CA, USA, 2000; Volume 319, pp. 59-67.

33. Yuan, Y.; Zhang, C.-J.; Xu, S.; Liu, B. A self-reporting AIE probe with a built-in singlet oxygen sensor for targeted photodynamic ablation of cancer cells. Chem. Sci. 2016, 7, 1862-1866. [CrossRef]

34. Zhou, Y.; Jiang, J.; Gao, Y.; Pang, S.Y.; Yang, Y.; Ma, J.; Gu, J.; Li, J.; Wang, Z.; Wang, L.H.; et al. Activation of peroxymonosulfate by phenols: Important role of quinone intermediates and involvement of singlet oxygen. Water Res. 2017, 125, 209-218. [CrossRef] [PubMed]

35. Li, C.X.; Wang, Y.J.; Chen, C.B.; Fu, X.Z.; Cui, S.; Lu, J.Y.; Liu, H.Q.; Li, W.W. Interactions between chlorophenols and peroxymonosulfate: $\mathrm{pH}$ dependency and reaction pathways. Sci. Total Environ. 2019, 664, 133-139. [CrossRef] [PubMed]

36. Koppenol, W.H.; Stanbury, D.M.; Bounds, P.L. Electrode potentials of partially reduced oxygen species, from dioxygen to water. Free Radic. Biol. Med. 2010, 49, 317-322. [CrossRef] [PubMed] 
37. Semyachkina-Glushkovskaya, O.V.; Sokolovski, S.G.; Goltsov, A.; Gekaluyk, A.S.; Saranceva, E.I.; Bragina, O.A.; Tuchin, V.V.; Rafailov, E.U. Laser-induced generation of singlet oxygen and its role in the cerebrovascular physiology. Prog. Quantum Electron. 2017, 55, 112-128. [CrossRef]

38. Niu, X.-Z.; Busetti, F.; Langsa, M.; Croué, J.-P. Roles of singlet oxygen and dissolved organic matter in self-sensitized photooxidation of antibiotic norfloxacin under sunlight irradiation. Water Res. 2016, 106, 214-222. [CrossRef]

39. Montgomery, R.E. Catalysis of peroxymonosulfate reactions by ketones. J. Am. Chem. Soc. 1974, 96, 7820-7821. [CrossRef]

40. Lange, A.; Brauer, H.D. On the formation of dioxiranes and of singlet oxygen by the ketone-catalysed decomposition of Caro's acid Journal of the chemical society perkin transactions. J. Chem. Soc. Perkin Trans. 1996, 25, 805-811. [CrossRef]

41. Zhou, Y.; Jiang, J.; Gao, Y.; Ma, J.; Pang, S.Y.; Li, J.; Lu, X.T.; Yuan, L.P. Activation of Peroxymonosulfate by Benzoquinone: A Novel Nonradical Oxidation Process. Environ. Sci. Technol. 2015, 49, 12941-12950. [CrossRef]

42. Gallopo, A.R.; Edwards, J.O. Kinetics and mechanism of the oxidation of pyridine by Caro's acid catalyzed by ketones. J. Org. Chem. 1981, 46, 1684-1688. [CrossRef]

43. Zhang, H.; Yu, K.; He, J.; Li, N.; You, H.; Jiang, J. Droplet spray ionization mass spectrometry for real-time monitoring of activation of peroxymonosulfate by 1,4-benzoquinone. Microchem. J. 2018, 139, 437-442. [CrossRef]

44. Li, C.-X.; Chen, C.-B.; Wang, Y.-J.; Fu, X.-Z.; Cui, S.; Lu, J.-Y.; Li, J.; Liu, H.-Q.; Li, W.-W.; Lau, T.-C. Insights on the pH-dependent roles of peroxymonosulfate and chlorine ions in phenol oxidative transformation. Chem. Eng. J. 2019, 362, 570-575. [CrossRef]

45. Qi, C.; Liu, X.; Ma, J.; Lin, C.; Li, X.; Zhang, H. Activation of peroxymonosulfate by base: Implications for the degradation of organic pollutants. Chemosphere 2016, 151, 280-288. [CrossRef]

46. Burns, J.M.; Cooper, W.J.; Ferry, J.L.; King, D.W.; DiMento, B.P.; McNeill, K.; Miller, C.J.; Miller, W.L.; Peake, B.M.; Rusak, S.A.; et al. Methods for reactive oxygen species (ROS) detection in aqueous environments. Aquat. Sci. 2012, 74, 683-734. [CrossRef]

47. Lou, X.; Fang, C.; Geng, Z.; Jin, Y.; Xiao, D.; Wang, Z.; Liu, J.; Guo, Y. Significantly enhanced base activation of peroxymonosulfate by polyphosphates: Kinetics and mechanism. Chemosphere 2017, 173, 529-534. [CrossRef]

48. Rao, L.; Yang, Y.; Chen, L.; Liu, X.; Chen, H.; Yao, Y.; Wang, W. Highly efficient removal of organic pollutants via a green catalytic oxidation system based on sodium metaborate and peroxymonosulfate. Chemosphere 2020, 238, 124687. [CrossRef] [PubMed]

49. Nie, M.; Zhang, W.; Yan, C.; Xu, W.; Wu, L.; Ye, Y.; Hu, Y.; Dong, W. Enhanced removal of organic contaminants in water by the combination of peroxymonosulfate and carbonate. Sci. Total Environ. 2019, 647, 734-743. [CrossRef]

50. Wang, S.; Wang, J. Treatment of membrane filtration concentrate of coking wastewater using PMS_chloridion oxidation process. Chem. Eng. J. 2019, 122361. [CrossRef]

51. Yang, F.; Huang, Y.; Fang, C.; Xue, Y.; Ai, L.; Liu, J.; Wang, Z. Peroxymonosulfate/base process in saline wastewater treatment: The fight between alkalinity and chloride ions. Chemosphere 2018, 199, 84-88. [CrossRef] [PubMed]

52. Xiao, R.; Luo, Z.; Wei, Z.; Luo, S.; Spinney, R.; Yang, W.; Dionysiou, D.D. Activation of peroxymonosulfate/persulfate by nanomaterials for sulfate radical-based advanced oxidation technologies. Curr. Opin. Chem. Eng. 2018, 19, 51-58. [CrossRef]

53. Duan, X.; Sun, H.; Ao, Z.; Zhou, L.; Wang, G.; Wang, S. Unveiling the active sites of graphene-catalyzed peroxymonosulfate activation. Carbon 2016, 107, 371-378. [CrossRef]

54. Chen, H.; Carroll, K.C. Metal-free catalysis of persulfate activation and organic-pollutant degradation by nitrogen-doped graphene and aminated graphene. Environ. Pollut. 2016, 215, 96-102. [CrossRef] [PubMed]

55. Liu, Y.; Miao, W.; Fang, X.; Tang, Y.; Wu, D.; Mao, S. MOF-derived metal-free N-doped porous carbon mediated peroxydisulfate activation via radical and non-radical pathways: Role of graphitic N and CO. Chem. Eng. J. 2020, 380, 122584. [CrossRef]

56. Ren, W.; Xiong, L.; Yuan, X.; Yu, Z.; Zhang, H.; Duan, X.; Wang, S. Activation of Peroxydisulfate on Carbon Nanotubes: Electron-Transfer Mechanism. Environ. Sci. Technol. 2019, 53, 14595-14603. [CrossRef] [PubMed]

57. Yun, E.-T.; Lee, J.H.; Kim, J.; Park, H.-D.; Lee, J. Identifying the Nonradical Mechanism in the Peroxymonosulfate Activation Process: Singlet Oxygenation Versus Mediated Electron Transfer. Environ. Sci. Technol. 2018, 52, 7032-7042. [CrossRef]

58. Yun, E.-T.; Yoo, H.-Y.; Bae, H.; Kim, H.-I.; Lee, J. Exploring the Role of Persulfate in the Activation Process: Radical Precursor Versus Electron Acceptor. Environ. Sci. Technol. 2017, 51, 10090-10099. [CrossRef]

59. Ren, W.; Xiong, L.; Nie, G.; Zhang, H.; Duan, X.; Wang, S. Insights into the Electron-Transfer Regime of Peroxydisulfate Activation on Carbon Nanotubes: The Role of Oxygen Functional Groups. Environ. Sci. Technol. 2020, 54, 1267-1275. [CrossRef]

60. Cheng, X.; Guo, H.; Zhang, Y.; Wu, X.; Liu, Y. Non-photochemical production of singlet oxygen via activation of persulfate by carbon nanotubes. Water Res. 2017, 113, 80-88. [CrossRef] [PubMed]

61. Sun, H.; Kwan, C.; Suvorova, A.; Ang, H.M.; Tadé, M.O.; Wang, S. Catalytic oxidation of organic pollutants on pristine and surface nitrogen-modified carbon nanotubes with sulfate radicals. Appl. Catal. B Environ. 2014, 154, 134-141. [CrossRef]

62. Ren, W.; Nie, G.; Zhou, P.; Zhang, H.; Duan, X.; Wang, S. The Intrinsic Nature of Persulfate Activation and N-Doping in Carbocatalysis. Environ. Sci. Technol. 2020, 54, 6438-6447. [CrossRef] [PubMed]

63. Duan, X.; Ao, Z.; Zhou, L.; Sun, H.; Wang, G.; Wang, S. Occurrence of radical and nonradical pathways from carbocatalysts for aqueous and nonaqueous catalytic oxidation. Appl. Catal. Environ. 2016, 188, 98-105. [CrossRef]

64. Wang, X.; Qin, Y.; Zhu, L.; Tang, H. Nitrogen-Doped Reduced Graphene Oxide as a Bifunctional Material for Removing Bisphenols: Synergistic Effect between Adsorption and Catalysis. Environ. Sci. Technol. 2015, 49, 6855-6864. [CrossRef] [PubMed]

65. Gao, Y.; Zhu, Y.; Lyu, L.; Zeng, Q.; Xing, X.; Hu, C. Electronic Structure Modulation of Graphitic Carbon Nitride by Oxygen Doping for Enhanced Catalytic Degradation of Organic Pollutants through Peroxymonosulfate Activation. Environ. Sci. Technol. 2018, 52, 14371-14380. [CrossRef] 
66. Liu, Z.; Zhang, L.; Sheng, L.; Zhou, Q.; Wei, T.; Feng, J.; Fan, Z. Edge-Nitrogen-Rich Carbon Dots Pillared Graphene Blocks with Ultrahigh Volumetric/Gravimetric Capacities and Ultralong Life for Sodium-Ion Storage. Adv. Energy Mater. $2018,8,1802042$. [CrossRef]

67. Kang, J.; Zhou, L.; Duan, X.; Sun, H.; Wang, S. Catalytic degradation of antibiotics by metal-free catalysis over nitrogen-doped graphene. Catal. Today 2018. [CrossRef]

68. Wang, S.; Xu, L.; Wang, J. Nitrogen-doped graphene as peroxymonosulfate activator and electron transfer mediator for the enhanced degradation of sulfamethoxazole. Chem. Eng. J. 2019, 375, 122041. [CrossRef]

69. Sun, P.; Liu, H.; Feng, M.; Guo, L.; Zhai, Z.; Fang, Y.; Zhang, X.; Sharma, V.K. Nitrogen-sulfur co-doped industrial graphene as an efficient peroxymonosulfate activator: Singlet oxygen-dominated catalytic degradation of organic contaminants. Appl. Catal. B Environ. 2019, 251, 335-345. [CrossRef]

70. Chen, X.; Oh, W.-D.; Hu, Z.-T.; Sun, Y.-M.; Webster, R.D.; Li, S.-Z.; Lim, T.-T. Enhancing sulfacetamide degradation by peroxymonosulfate activation with $\mathrm{N}$-doped graphene produced through delicately-controlled nitrogen functionalization via tweaking thermal annealing processes. Appl. Catal. B Environ. 2018, 225, 243-257. [CrossRef]

71. Guo, Y.; Zeng, Z.; Zhu, Y.; Huang, Z.; Cui, Y.; Yang, J. Catalytic oxidation of aqueous organic contaminants by persulfate activated with sulfur-doped hierarchically porous carbon derived from thiophene. Appl. Catal. B Environ. 2018, 220, 635-644. [CrossRef]

72. Chen, X.; Duan, X.; Oh, W.-D.; Zhang, P.-H.; Guan, C.-T.; Zhu, Y.-A.; Lim, T.-T. Insights into nitrogen and boron-co-doped graphene toward high-performance peroxymonosulfate activation: Maneuverable N-B bonding configurations and oxidation pathways. Appl. Catal. B Environ. 2019, 253, 419-432. [CrossRef]

73. Zhang, B.; Wu, T.; Sun, D.; Chen, W.; Li, G.; Li, Y. NH2-MCM-41 supported on nitrogen-doped graphene as bifunctional composites for removing phenol compounds: Synergistic effect between catalytic degradation and adsorption. Carbon 2019, 147, 312-322. [CrossRef]

74. Deng, B.; Wang, D.; Jiang, Z.; Zhang, J.; Shi, S.; Jiang, Z.-J.; Liu, M. Amine group induced high activity of highly torn amine functionalized nitrogen-doped graphene as the metal-free catalyst for hydrogen evolution reaction. Carbon 2018, 138, 169-178. [CrossRef]

75. Yu, J.; Zhu, Z.; Zhang, H.; Di, G.; Qiu, Y.; Yin, D.; Wang, S. Hydrochars from pinewood for adsorption and nonradical catalysis of bisphenols. J. Hazard. Mater. 2020, 385, 121548. [CrossRef] [PubMed]

76. Huang, B.-C.; Jiang, J.; Huang, G.-X.; Yu, H.-Q. Sludge biochar-based catalysts for improved pollutant degradation by activating peroxymonosulfate. J. Mater. Chem. A 2018, 6, 8978-8985. [CrossRef]

77. Ding, D.; Yang, S.; Qian, X.; Chen, L.; Cai, T. Nitrogen-doping positively whilst sulfur-doping negatively affect the catalytic activity of biochar for the degradation of organic contaminant. Appl. Catal. B Environ. 2020, 263, 118348. [CrossRef]

78. Wu, D.; Song, W.; Chen, L.; Duan, X.; Xia, Q.; Fan, X.; Li, Y.; Zhang, F.; Peng, W.; Wang, S. High-performance porous graphene from synergetic nitrogen doping and physical activation for advancednonradical oxidation. J. Hazard. Mater. 2020, 381, 121010. [CrossRef] [PubMed]

79. Yin, R.; Guo, W.; Wang, H.; Du, J.; Wu, Q.; Chang, J.-S.; Ren, N. Singlet oxygen-dominated peroxydisulfate activation by sludge-derived biochar for sulfamethoxazole degradation through a nonradical oxidation pathway: Performance and mechanism. Chem. Eng. J. 2019, 357, 589-599. [CrossRef]

80. Mian, M.M.; Liu, G. Activation of peroxymonosulfate by chemically modified sludge biochar for the removal of organic pollutants: Understanding the role of active sites and mechanism. Chem. Eng. J. 2020, 392, 123681. [CrossRef]

81. Hu, W.; Xie, Y.; Lu, S.; Li, P.; Xie, T.; Zhang, Y.; Wang, Y. One-step synthesis of nitrogen-doped sludge carbon as a bifunctional material for the adsorption and catalytic oxidation of organic pollutants. Sci. Total Environ. 2019, 680, 51-60. [CrossRef]

82. Lee, H.; Kim, H.-i.; Weon, S.; Choi, W.; Hwang, Y.S.; Seo, J.; Lee, C.; Kim, J.-H. Activation of Persulfates by Graphitized Nanodiamonds for Removal of Organic Compounds. Environ. Sci. Technol. 2016, 50, 10134-10142. [CrossRef]

83. Duan, X.; Ao, Z.; Zhang, H.; Saunders, M.; Sun, H.; Shao, Z.; Wang, S. Nanodiamonds in sp2/sp3configuration for radical to nonradical oxidation: Core-shell layer dependence. Appl. Catal. B Environ. 2018, 222, 176-181. [CrossRef]

84. Feng, L.; Li, X.; Chen, X.; Huang, Y.; Peng, K.; Huang, Y.; Yan, Y.; Chen, Y. Pig manure-derived nitrogen-doped mesoporous carbon for adsorption and catalytic oxidation of tetracycline. Sci. Total Environ. 2020, 708, 135071. [CrossRef] [PubMed]

85. Jiang, L.; Zhang, Y.; Zhou, M.; Liang, L.; Li, K. Oxidation of Rhodamine B by persulfate activated with porous carbon aerogel through a non-radical mechanism. J. Hazard. Mater. 2018, 358, 53-61. [CrossRef]

86. Chen, X.; Oh, W.-D.; Zhang, P.-H.; Webster, R.D.; Lim, T.-T. Surface construction of nitrogen-doped chitosan-derived carbon nanosheets with hierarchically porous structure for enhanced sulfacetamide degradation via peroxymonosulfate activation: Maneuverable porosity and active sites. Chem. Eng. J. 2020, 382, 122908. [CrossRef]

87. Ahn, Y.-Y.; Bae, H.; Kim, H.-I.; Kim, S.-H.; Kim, J.-H.; Lee, S.-G.; Lee, J. Surface-loaded metal nanoparticles for peroxymonosulfate activation: Efficiency and mechanism reconnaissance. Appl. Catal. B Environ. 2019, 241, 561-569. [CrossRef]

88. Du, X.; Zhang, Y.; Si, F.; Yao, C.; Du, M.; Hussain, I.; Kim, H.; Huang, S.; Lin, Z.; Hayat, W. Persulfate non-radical activation by nano-CuO for efficient removal of chlorinated organic compounds: Reduced graphene oxide-assisted and $\mathrm{CuO}(001)$ facetdependent. Chem. Eng. J. 2019, 356, 178-189. [CrossRef]

89. Xiong, X.; Sun, B.; Zhang, J.; Gao, N.; Shen, J.; Li, J.; Guan, X. Activating persulfate by Fe0 coupling with weak magnetic field: Performance and mechanism. Water Res. 2014, 62, 53-62. [CrossRef] 
90. Li, W.; Zhang, Y.; Zhao, P.; Zhou, P.; Liu, Y.; Cheng, X.; Wang, J.; Yang, B.; Guo, H. Enhanced kinetic performance of peroxymonosulfate/ZVI system with the addition of copper ions: Reactivity, mechanism, and degradation pathways. J. Hazard. Mater. 2020, 393, 122399. [CrossRef]

91. Yang, S.; Wu, P.; Liu, J.; Chen, M.; Ahmed, Z.; Zhu, N. Efficient removal of bisphenol A by superoxide radical and singlet oxygen generated from peroxymonosulfate activated with Fe0-montmorillonite. Chem. Eng. J. 2018, 350, 484-495. [CrossRef]

92. Kim, C.; Ahn, J.-Y.; Kim, T.Y.; Shin, W.S.; Hwang, I. Activation of Persulfate by Nanosized Zero-Valent Iron (NZVI): Mechanisms and Transformation Products of NZVI. Environ. Sci. Technol. 2018, 52, 3625-3633. [CrossRef] [PubMed]

93. Pi, Z.; Li, X.; Wang, D.; Xu, Q.; Tao, Z.; Huang, X.; Yao, F.; Wu, Y.; He, L.; Yang, Q. Persulfate activation by oxidation biochar supported magnetite particles for tetracycline removal: Performance and degradation pathway. J. Clean. Prod. 2019, 235, 1103-1115. [CrossRef]

94. Feng, M.; Qu, R.; Zhang, X.; Sun, P.; Sui, Y.; Wang, L.; Wang, Z. Degradation of flumequine in aqueous solution by persulfate activated with common methods and polyhydroquinone-coated magnetite/multi-walled carbon nanotubes catalysts. Water Res. 2015, 85, 1-10. [CrossRef]

95. Liu, L.; Xu, X.; Li, Y.; Su, R.; Li, Q.; Zhou, W.; Gao, B.; Yue, Q. One-step synthesis of "nuclear-shell" structure iron-carbon nanocomposite as a persulfate activator for bisphenol A degradation. Chem. Eng. J. 2020, 382, 122780. [CrossRef]

96. Zhu, S.; Wang, W.; Xu, Y.; Zhu, Z.; Liu, Z.; Cui, F. Iron sludge-derived magnetic Fe0/Fe3C catalyst for oxidation of ciprofloxacin via peroxymonosulfate activation. Chem. Eng. J. 2019, 365, 99-110. [CrossRef]

97. Zhang, G.; Ding, Y.; Nie, W.; Tang, H. Efficient degradation of drug ibuprofen through catalytic activation of peroxymonosulfate by Fe3C embedded on carbon. J. Environ. Sci. 2019, 78, 1-12. [CrossRef] [PubMed]

98. Wu, S.; Liu, H.; Yang, C.; Li, X.; Lin, Y.; Yin, K.; Sun, J.; Teng, Q.; Du, C.; Zhong, Y. High-performance porous carbon catalysts doped by iron and nitrogen for degradation of bisphenol F via peroxymonosulfate activation. Chem. Eng. J. 2020, 392, 123683. [CrossRef]

99. Liu, K.; Yu, M.; Wang, H.; Wang, J.; Liu, W.; Hoffmann, M.R. Multiphase Porous Electrochemical Catalysts Derived from Iron-Based Metal-Organic Framework Compounds. Environ. Sci. Technol. 2019, 53, 6474-6482. [CrossRef]

100. Liang, S.-X.; Wang, X.; Zhang, W.; Liu, Y.-J.; Wang, W.; Zhang, L.-C. Selective laser melting manufactured porous Fe-based metallic glass matrix composite with remarkable catalytic activity and reusability. Appl. Mater. Today 2020, 19, 100543. [CrossRef]

101. Liang, S.-X.; Jia, Z.; Zhang, W.C.; Li, X.F.; Wang, W.M.; Lin, H.C.; Zhang, L.C. Ultrafast activation efficiency of three peroxides by Fe78Si9B13 metallic glass under photo-enhanced catalytic oxidation: A comparative study. Appl. Catal. B Environ. 2018, 221, 108-118. [CrossRef]

102. Xie, M.; Tang, J.; Fang, G.; Zhang, M.; Kong, L.; Zhu, F.; Ma, L.; Zhou, D.; Zhan, J. Biomass Schiff base polymer-derived N-doped porous carbon embedded with $\mathrm{CoO}$ nanodots foradsorption and catalytic degradation of chlorophenol by peroxymonosulfate. J. Hazard. Mater. 2020, 384, 121345. [CrossRef]

103. Anipsitakis, G.P.; Dionysiou, D.D. Radical Generation by the Interaction of Transition Metals with Common Oxidants. Environ. Sci. Technol. 2004, 38, 3705-3712. [CrossRef] [PubMed]

104. Zhang, Q.; He, D.; Li, X.; Feng, W.; Lyu, C.; Zhang, Y. Mechanism and performance of singlet oxygen dominated peroxymonosulfate activation on $\mathrm{CoOOH}$ nanoparticles for 2,4-dichlorophenol degradation in water. J. Hazard. Mater. 2020, 384 , 121350. [CrossRef]

105. Wu, L.; Zhang, Q.; Hong, J.; Dong, Z.; Wang, J. Degradation of bisphenol A by persulfate activation via oxygen vacancy-rich CoFe2O4-x. Chemosphere 2019, 221, 412-422. [CrossRef]

106. Zhu, C.; Zhang, Y.; Fan, Z.; Liu, F.; Li, A. Carbonate-enhanced catalytic activity and stability of Co3O4 nanowires for 1O2-driven bisphenol A degradation via peroxymonosulfate activation: Critical roles of electron and proton acceptors. J. Hazard. Mater. 2020, 393, 122395. [CrossRef] [PubMed]

107. Tian, W.; Zhang, H.; Qian, Z.; Ouyang, T.; Sun, H.; Qin, J.; Tadé, M.O.; Wang, S. Bread-making synthesis of hierarchically Co@C nanoarchitecture in heteroatom doped porous carbons for oxidative degradation of emerging contaminants. Appl. Catal. B Environ. 2018, 225, 76-83. [CrossRef]

108. Zhang, S.; Gao, H.; Xu, X.; Cao, R.; Yang, H.; Xu, X.; Li, J. MOF-derived CoN/N-C@SiO2yolk-shell nanoreactor with dual active sites for highly efficient catalytic advanced oxidation processes. Chem. Eng. J. 2020, 381, 122670. [CrossRef]

109. Ding, D.; Yang, S.; Chen, L.; Cai, T. Degradation of norfloxacin by CoFe alloy nanoparticles encapsulated in nitrogen doped graphitic carbon (CoFe@N-GC) activated peroxymonosulfate. Chem. Eng. J. 2020, 392, 123725. [CrossRef]

110. Liu, C.; Liu, S.; Liu, L.; Tian, X.; Liu, L.; Xia, Y.; Liang, X.; Wang, Y.; Song, Z.; Zhang, Y.; et al. Novel carbon based Fe-Co oxides derived from Prussian blue analogues activating peroxymonosulfate: Refractory drugs degradation without metal leaching. Chem. Eng. J. 2020, 379, 122274. [CrossRef]

111. Taujale, S.; Baratta, L.R.; Huang, J.; Zhang, H. Interactions in Ternary Mixtures of $\mathrm{MnO}_{2}, \mathrm{Al}_{2} \mathrm{O}_{3}$, and Natural Organic Matter (NOM) and the Impact on $\mathrm{MnO}_{2}$ Oxidative Reactivity. Environ. Sci. Technol. 2016, 50, 2345-2353. [CrossRef]

112. Zeng, Z.; Khan, A.; Wang, Z.; Zhao, M.; Mo, W.; Chen, Z. Elimination of atrazine through radical/non-radical combined processes by manganese nano-catalysts/PMS and implications to the structure-performance relationship. Chem. Eng. J. 2020, $397,125425$. [CrossRef]

113. Huang, J.; Dai, Y.; Singewald, K.; Liu, C.-C.; Saxena, S.; Zhang, H. Effects of MnO2of different structures on activation of peroxymonosulfate. Chem. Eng. J. 2019, 370, 906-915. [CrossRef] 
114. Fan, J.; Qin, H.; Jiang, S. Mn-doped g-C3N4 composite to activate peroxymonosulfate for acetaminophen degradation: The role of superoxide anion and singlet oxygen. Chem. Eng. J. 2019, 359, 723-732. [CrossRef]

115. Yu, J.; Zeng, T.; Wang, H.; Zhang, H.; Sun, Y.; Chen, L.; Song, S.; Li, L.; Shi, H. Oxygen-defective MnO2-x rattle-type microspheres mediated singlet oxygen oxidation of organics by peroxymonosulfate activation. Chem. Eng. J. 2020, 394, 124458. [CrossRef]

116. Xing, S.; Li, W.; Liu, B.; Wu, Y.; Gao, Y. Removal of ciprofloxacin by persulfate activation with CuO: A pH-dependent mechanism. Chem. Eng. J. 2020, 382, 122837. [CrossRef]

117. Wang, S.; Gao, S.; Tian, J.; Wang, Q.; Wang, T.; Hao, X.; Cui, F. A stable and easily prepared copper oxide catalyst for degradation of organic pollutants by peroxymonosulfate activation. J. Hazard. Mater. 2020, 387, 121995. [CrossRef] [PubMed]

118. Li, Z.; Sun, Y.; Huang, W.; Xue, C.; Zhu, Y.; Wang, Q.; Liu, D. Innovatively employing magnetic CuO nanosheet to activate peroxymonosulfate for the treatment of high-salinity organic wastewater. J. Environ. Sci. 2020, 88, 46-58. [CrossRef]

119. Li, Z.; Liu, D.; Huang, W.; Wei, X.; Huang, W. Biochar supported CuO composites used as an efficient peroxymonosulfate activator for highly saline organic wastewater treatment. Sci. Total Environ. 2020, 721, 137764. [CrossRef] [PubMed]

120. Shahzad, A.; Ali, J.; Ifthikar, J.; Aregay, G.G.; Zhu, J.; Chen, Z.; Chen, Z. Non-radical PMS activation by the nanohybridmaterial with periodic confinement of reduced graphene oxide (rGO) and $\mathrm{Cu}$ hydroxides. J. Hazard. Mater. 2020, 392, 122316. [CrossRef]

121. Dong, X.; Duan, X.; Sun, Z.; Zhang, X.; Li, C.; Yang, S.; Ren, B.; Zheng, S.; Dionysiou, D.D. Natural illite-based ultrafine cobalt oxide with abundant oxygen-vacancies for highly efficient Fenton-like catalysis. Appl. Catal. B Environ. 2020, $261,118214$. [CrossRef]

122. Yu, R.; Zhao, J.; Zhao, Z.; Cui, F. Copper substituted zinc ferrite with abundant oxygen vacancies for enhanced ciprofloxacin degradation via peroxymonosulfate activation. J. Hazard. Mater. 2020, 390, 121998. [CrossRef] [PubMed]

123. Li, Z.; Liu, D.; Zhao, Y.; Li, S.; Wei, X.; Meng, F.; Huang, W.; Lei, Z. Singlet oxygen dominated peroxymonosulfate activation by $\mathrm{CuO}-\mathrm{CeO} 2$ for organic pollutants degradation: Performance and mechanism. Chemosphere 2019, 233, 549-558. [CrossRef]

124. Jawad, A.; Zhan, K.; Wang, H.; Shahzad, A.; Zeng, Z.; Wang, J.; Zhou, X.; Ullah, H.; Chen, Z.; Chen, Z. Tuning of Persulfate Activation from a Free Radical to a Nonradical Pathway through the Incorporation of Non-Redox Magnesium Oxide. Environ. Sci. Technol. 2020, 54, 2476-2488. [CrossRef] [PubMed]

125. Chen, Z.; Bi, S.; Zhao, G.; Chen, Y.; Hu, Y. Enhanced degradation of triclosan by cobalt manganese spinel-type oxide activated peroxymonosulfate oxidation process via sulfate radicals and singlet oxygen: Mechanisms and intermediates identification. Sci. Total Environ. 2020, 711, 134715. [CrossRef] [PubMed]

126. Zhao, Q.; Yan, Z.; Chen, C.; Chen, J. Spinels: Controlled preparation, oxygen reduction/evolution reaction application, and beyond. Chem. Rev. 2017, 117, 10121-10211. [CrossRef]

127. Zhao, Y.; An, H.; Dong, G.; Feng, J.; Wei, T.; Ren, Y.; Ma, J. Oxygen vacancies induced heterogeneous catalysis of peroxymonosulfate by Ni-doped AgFeO2materials: Evolution of reactive oxygen species and mechanism. Chem. Eng. J. 2020, $388,124371$. [CrossRef]

128. Deng, J.; Cheng, Y.-Q.; Lu, Y.-A.; Crittenden, J.C.; Zhou, S.-Q.; Gao, N.-Y.; Li, J. Mesoporous manganese Cobaltite nanocages as effective and reusable heterogeneous peroxymonosulfate activators for Carbamazepine degradation. Chem. Eng. J. 2017, 330, 505-517. [CrossRef]

129. Li, C.; Wu, J.; Peng, W.; Fang, Z.; Liu, J. Peroxymonosulfate activation for efficient sulfamethoxazole degradation by Fe3O4/ $\beta$ FeOOH nanocomposites: Coexistence of radical and non-radical reactions. Chem. Eng. J. 2019, 356, 904-914. [CrossRef]

130. Lu, S.; Wang, G.; Chen, S.; Yu, H.; Ye, F.; Quan, X. Heterogeneous activation of peroxymonosulfate by LaCo1-xCuxO3 perovskites for degradation of organic pollutants. J. Hazard. Mater. 2018, 353, 401-409. [CrossRef]

131. Ahn, Y.-Y.; Yun, E.-T.; Seo, J.-W.; Lee, C.; Kim, S.H.; Kim, J.-H.; Lee, J. Activation of Peroxymonosulfate by Surface-Loaded Noble Metal Nanoparticles for Oxidative Degradation of Organic Compound. Environ. Sci. Technol. 2016, 50, 10187-10197. [CrossRef]

132. Wang, Y.; Cao, D.; Liu, M.; Zhao, X. Insights into heterogeneous catalytic activation of peroxymonosulfate by $\mathrm{Pd} / \mathrm{g}-\mathrm{C}_{3} \mathrm{~N}_{4}$ : The role of superoxide radical and singlet oxygen. Catal. Commun. 2017, 102, 85-88. [CrossRef]

133. Luo, R.; Li, M.; Wang, C.; Zhang, M.; Nasir Khan, M.A.; Sun, X.; Shen, J.; Han, W.; Wang, L.; Li, J. Singlet oxygen-dominated non-radical oxidation process for efficient degradation of bisphenol Aunder high salinity condition. Water Res. 2019, 148, 416-424 [CrossRef] [PubMed]

134. Yang, X.; Cai, J.; Wang, X.; Li, Y.; Wu, Z.; Wu, W.D.; Chen, X.D.; Sun, J.; Sun, S.P.; Wang, Z. A Bimetallic Fe-Mn Oxide-Activated Oxone for In Situ Chemical Oxidation (ISCO) of Trichloroethylene in Groundwater: Efficiency, Sustained Activity, and Mechanism Investigation. Environ. Sci. Technol. 2020, 54, 3714-3724. [CrossRef] [PubMed]

135. Yu, M.; Teel, A.L.; Watts, R.J. Activationof Peroxymonosulfate by Subsurface Minerals. J. Contam. Hydrol. 2016, 191, 33-43. [CrossRef] [PubMed]

136. Ahmad, M.; Teel, A.L.; Watts, R.J. Persulfate activation by subsurface minerals. J. Contam. 2010, 115, 34-45. [CrossRef]

137. Sra, K.S.; Thomson, N.R.; Barker, J.F. Persulfate injection into a gasoline source zone. J. Contam. Hydrol. 2013, 150, 35-44. [CrossRef] 